\title{
The Schmitelsen Court: The Question of Legitimacy
}

\author{
Or Bassok ${ }^{*}$
}

(Received 18 October 2018; accepted 4 February 2019)

\begin{abstract}
In recent years, a new creature has emerged on the institutional landscape: The Schmitelsen Court. This court is the end-product of a combination of the positions presented by Hans Kelsen and Carl Schmitt in their famous debate over the institutional identity of the guardian of the constitution during the Weimar years. The Schmitelsen guardian is a court thus fulfilling Kelsen's vision of the constitutional court as the guardian of the constitution. Nevertheless, it possesses the mission, the means to achieve it, and the source of legitimacy that Schmitt envisioned for the president as the guardian of the constitution. In this Article, I focus on the Schmitelsen Court's source of legitimacy that differs greatly from the traditional source of judicial legitimacy that Kelsen envisioned for the guardian. Whereas Kelsen viewed legal expertise as the guardian's source of legitimacy, Schmitt viewed public support as filling this role. After analyzing these two positions, I explain why it is vital for the Schmitelsen Court to harness public support as its source of legitimacy. I proceed by examining how the Schmitelsen Court model manifests itself in three case studies. In the US, Alexander Hamilton-in The Federalist No. 78-raised the notion of the guardian of the constitution long before Schmitt and Kelsen. He designated the judiciary as the guardian and ascribed its source of legitimacy to expertise. After describing how in recent decades the US Supreme Court adopted the Schmitelsen understanding of judicial legitimacy, I turn to examine the Israeli Supreme Court and the European Court of Human Rights. The relevance of these latter two courts stems not only from their adoption of the Schmitelsen Court's understanding of judicial legitimacy, but also from the strong influence of the Weimar lessons on their evolution into Schmitelsen guardians.
\end{abstract}

Keywords: Hans Kelsen; Carl Schmitt; Weimar; US Supreme Court; Israeli Supreme Court; EctHR

\section{A. Introduction}

While the metaphor of the guardian of the constitution has roots in the work of Sieyès and Hamilton, among others, ${ }^{1}$ it came to the forefront of constitutional discussion during the turbulent years of the Weimar Republic with the debate between Carl Schmitt and Hans Kelsen over the institutional identity of the guardian of the constitution. ${ }^{2}$ Because Germany's first experiment with

\footnotetext{
*Assistant Professor at the School of Law of the University of Nottingham. This Article was long in the making. Previous drafts were presented at the Judges as Guardians of Constitutionalism and Human Rights Conference held at the EUI in 2014, at NYU workshop on populism, and at Oxford OxonCourts workshop. I am grateful for valuable comments from participants in these events and especially to Marina Aksenova, Helle Krunke, Ming-Sung Kuo, and Martin Scheinin. Special thanks to Bruce Ackerman, Paul Kahn, Robert Post, Ruth Gavison, and Aharon Barak, who gave excellent comments to various papers I have written that served as the basis for this Article. Sarah Thin provided excellent research assistance. All errors are my own.

${ }^{1}$ See The Federalist No. 78 in The Federalist Papers, 392 (Alexander Hamilton) (Ian Shapiro ed., 2009); Marco Goldoni, At the Origins of Constitutional Review: Sieyes' Constitutional Jury and the Taming of Constituent Power, 32 OXFORD J. LEGAL STUD. 211, 211 (2012).

${ }^{2}$ Hans Kelsen \& Carl Schmitt, The Guardian of the Constitution: Hans Kelsen and Carl Schmitt on the Limits of Constitutional LAW (Lars Vinx trans., 2015).
}

() The Author(s) 2020. Published by Cambridge University Press on behalf of the German Law Journal. This is an Open Access article, distributed under the terms of the Creative Commons Attribution-NonCommercial licence (http://creativecommons.org/licenses/by-nc/4.0/), which permits unrestricted re-use, distribution, and reproduction in any medium, provided the original work is properly cited. 
democracy failed with this fierce debate in the background, its lessons still loom large. ${ }^{3}$ The debate is usually presented in a rather schematic way with Schmitt arguing for the president as the guardian and Kelsen arguing for the constitutional court. If we adopt this simplistic depiction, in retrospect, Kelsen is the clear winner of the debate, because in many countries worldwide, national high courts ${ }^{4}$ are depicted as the guardian of their respective constitutions. ${ }^{5}$ I argue, however, that if we look more closely at the arguments presented by both scholars, our conclusion would be quite different.

For Schmitt, the guardian protects the basic political decision of the polity-its identity-as manifested in the constitution. In order to protect this decision, the guardian must have the support of the people. However, as courts, according to Schmitt, cannot base their legitimacy on the support of the people, they cannot serve as the guardian of the constitution. Only the Reich president who enjoys the people's support can. Kelsen designates the role of the guardian to the constitutional court out of a different understanding of the object that needs protection. According to Kelsen, constitutional law is a system aimed to accommodate peaceful democratic process; it is not an arena for existential politics. In order to ensure the systematic integrity of constitutional law, a judicial institution is required. According to this picture of reality, the guardian's source of legitimacy would be its expertise in law rather than public support.

In recent decades, a new creature has emerged: The Schmitelsen Court. This court can be conceptualized as adopting Kelsen's vision of the designated guardian while acting in the manner Schmitt envisioned for his guardian. First, the Schmitelsen Court protects the polity's identity; second, it uses means that are far beyond those Kelsen allowed his guardian to employ; and third, it relies on the people's support as its source of legitimacy, as Schmitt thought is essential for the guardian. My discussion in this Article focuses on the Schmitelsen guardian's source of legitimacy. There are connections between the two other characteristics of the Schmitelsen guardian and its source of legitimacy. Only by harnessing public support as its source of legitimacy can the Schmitelsen guardian fulfill its role as a protector of the polity's identity while using extraordinary means. For this reason, I discuss the two other characteristics of the Schmitelsen guardian as far as they are relevant to the discussion of its source of legitimacy.

There are undoubtedly many important issues raised in the debate between Kelsen and Schmitt that warrant analysis. I chose to focus on the source of the guardian's legitimacy for two main reasons. First, this issue has yet to receive any serious attention by scholars who write on Schmitt and Kelsen. Second, in recent decades, the concept of judicial legitimacy has been transformed in many legal systems, and the debate between Kelsen and Schmitt sheds an important light on this crucial development.

I begin by presenting Schmitt's and Kelsen's positions on the guardian's source of legitimacy, the connections between this issue and the guardian's mission, and the means to achieve this mission (Section B). Next, I argue that a recent shift in the understanding of judicial legitimacy in the US is in line with a Schmitelsen understanding of the guardian's source of legitimacy (Section C). In the following two sections, I analyze two examples of courts adopting the Schmitelsen understanding of judicial legitimacy based, in part, on their reading of the Weimar experience (Sections D and E). I focus on these two courts mainly due to the explicit connection between their understanding of judicial legitimacy and their reading of the Weimar experience. In other words, while the conceptual shift in understanding judicial legitimacy can be elaborated without connecting it to the Kelsen-Schmitt debate, these two courts present case studies in which the Weimar "lessons" were influential in bringing about this shift. Thus, I do not purport to present a comprehensive

\footnotetext{
${ }^{3}$ See David Dyzenhaus, Legal Theory in the Collapse of Weimar: Contemporary Lessons?, 91 AM. POL. SCI. REv. 121 (1997).

${ }^{4}$ I use the term "national high courts" to include both constitutional courts and supreme courts.

${ }^{5}$ See, e.g., Justin Collings, Democracy's Guardians: A History of the German Federal Constitutional Court, 1951-2001, at xxix (2015) ("Now in its seventh decade, the self-proclaimed 'Guardian of the Constitution' (Hüter der Verfassung) sits secure at the centre of the German legal and political order.").
} 
description of these two courts' affinity to the Schmitelsen understanding of judicial legitimacy. Rather,

I focus on the use of the Weimar experience to promote this shift in both examples. In Section D, I argue that the Israeli Supreme Court, influenced by its understanding of the "Weimar lessons" and under the leadership of Judge Aharon Barak, shifted its understanding of judicial legitimacy as part of its transformation into the guardian of the constitution. In Section E, I argue that, during the creation of the European Convention on Human Rights, the fear of a collapse, similar to the one the Weimar Republic experienced, led to an understanding of judicial legitimacy in terms of public support. This understanding continues to be present in the European Court of Human Rights judgments.

Before delving into the discussion, a conceptual clarification is required in order to avoid reading Schmitt through our current conceptual lens rather than through his. Throughout the history of political thought, the concept of "the political" has been said in many ways. ${ }^{6}$ In the context of constitutional theory, it is essential to distinguish between three meanings of the concept. First, the political is the realm of existential decisions of the highest degree of intensity. ${ }^{7}$ It is the decision on which the concrete identity of the state rests. When people speak of dying for the state in the name of certain values, they speak of sacrificing their lives for its political existence. ${ }^{8}$ Second, the political is the realm in which we debate competing values. This is the domain-sometimes referred to as "high politics"- where we express our wants and desires in a language that presumes rational persuasion. ${ }^{9}$ In current constitutional discourse, the language of rights and policy considerations best expresses this meaning of the term political. In its third sense, the political is reduced to personal motivation and power, void of distinct content. Correctness in this realm of politics is determined by the power in the political arena held by the proponents of a position rather than by the persuasiveness of their arguments or by a fight for life or death. ${ }^{10}$ This conceptualization of the political is sometimes referred to as "low politics"11 or "partisan politics." ${ }^{12}$ Schmitt at times uses the term "political" to denote the second and the third meanings, ${ }^{13}$ but it is important to stress that

contrary to our current use, he also uses the term to denote the existential decision, anchored in the constitution, that defines the polity's identity. ${ }^{14}$ In Schmitt's world, one dies for the political; ${ }^{15}$

\footnotetext{
${ }^{6}$ Compare to Aristotle's claim in the Metaphysics that "[b]eing is said of in many ways ...." ARISTOTLE, Metaphysics VII.1 (1028A-10).

${ }^{7}$ See Carl Schmitt, The Concept of the Political 25-27 (George Schwab trans., 1996) (1928). See also William E. SCHEUERMAN, CARL SCHMITT: THE END OF LAW 229-40 (1999) (noting that for Schmitt, "politics can spring up in a host of distinct arenas of human existence ... when it gains an especially intense character ..." and showing that Schmitt had effectively plagiarized the intensity idea from Hans Morgenthau); BenJAmin SCHUPMANn, CARL SCHMITT's STATE AND Constitutional Theory: A Critical Analysis 82 (2017) ("Political values are existential because, from the perspective of those committed to them, to be deprived of them would render life not worth living.").

${ }^{8}$ See Paul W. Kahn, Political Theology: Four New Chapters on the Concept of Sovereignty 57-58 (2011).

${ }^{9}$ See, e.g., Jack M. Balkin \& Sanford Levinson, Understanding the Constitutional Revolution, 87 VA. L. REV. 1045, 1062-63 (2001) (explicating "a distinction between two kinds of politics - 'high politics,' which involves struggles over competing values and ideologies, and 'low politics,' which involves struggles over which group or party will hold power”).

${ }^{10}$ See Michel Foucault, Nietzsche, Genealogy, History, in The Foucault Reader 76, 79 (Paul Rabinow ed., 1984).

${ }^{11}$ See Sanford Levinson, Return of Legal Realism, NATION 8 (Jan. 8, 2001) (“Though judges are 'political,' the politics are 'high' rather than 'low'; that is, decisions are based on ideology rather than a simple desire to help out one's political friends in the short run.").

${ }^{12}$ See Alec Stone Sweet, The Politics of Constitutional Review in France and Europe, 5 INT'L J. Const. L. 69, 73 (2007) (discussing the claim that constitutional judging is political).

${ }^{13}$ See, e.g., SCHмiтT, supra note 7, at 30 (explaining that "the most peculiar dealings and manipulations" that are the "banal forms" of the political "are called politics").

${ }^{14}$ See John P. McCormick, Carl SchmitT's Critique of Liberalism: Against Politics as Technology 230-36, 251 (1997); Ernst-Wolfgang Böckenförde, The Concept of the Political: A Key to Understanding Carl Schmitt's Constitutional Theory, in LAW As Politics 37, 42-45 (David Dyzenhaus ed., 1998).
} 
in our world, such a saying would raise eyebrows. No one dies for the Labour party or the Republican party. ${ }^{16}$

Beyond making sure that Schmitt is understood properly, I have an ulterior motive in emphasizing the shift in understanding the concept of the political from Schmitt's time to ours. In this Article, I argue that a shift has occurred in the understanding of the concept of judicial legitimacy in several legal systems. The shift in understanding the concept of the political demonstrates how this type of conceptual shifts occurs: The terminology remains static while its meaning changes significantly.

\section{B. The Guardian's Source of Legitimacy}

Schmitt states that without "an independent authority in a democratic constitution ... there can be no guardian of the constitution." ${ }^{17}$ He explains that independence of the judge- one of the "very different kinds of independence" 18 — is based on expertise, and the independence of the Reich president is based on the "plebiscitary element of the constitution of the Reich." ${ }^{19}$ The difference in the basis upon which their independence is built makes the judge ill-equipped to be the guardian of the constitution for two reasons. First, defending the political decision that stands at the core of the constitution is beyond the realm of judicial expertise and would lead necessarily to the politicization of the judiciary. Second, if the need arises to protect the polity's most basic decision against the democratically elected parliament, the guardian would not be able to effectively confront parliament unless its source of independence emanates from the people. Let me expand on these two reasons.

Schmitt writes that "[ $t$ ]he guardian of the constitution must indeed be independent and partypolitically neutral." ${ }^{20}$ Schmitt does not require the guardian to be apolitical in the sense of having a neutral position in existential politics. For him, the chief task of the guardian is to protect the nation's existential decision, which is an inherently political determination. In his mind, the result of the division and pluralism in the Weimar parliament was its inability to take existential political decisions in the name of the people. Schmitt requires only neutrality from partisan politics, from the splintering of parties in parliament. ${ }^{21}$ Both the judge and the president can achieve this independence from partisan politics. ${ }^{22}$

The polity's existential political decision, however, is outside the realm of judicial expertise, and for this reason, stands in tension with judicial independence. "The independence of judges," writes Schmitt, "is merely the other side of the judicial subjection to statute, and is therefore non-political." 23 In other words, judicial independence is enabled and justified by judges being bound to a statute; by judges deciding according to legal expertise. ${ }^{24}$ The judge is independent only in the sense that $\mathrm{s} / \mathrm{he}$ is

\footnotetext{
${ }^{15}$ See ScHMitT, supra note 7, at 35, 71 ("In a case of need, the political entity must demand the sacrifice of life. Such a demand is in no way justifiable by the individualism of liberal thought .... For the individual as such there is no enemy with whom he must enter into a life-and-death struggle if he personally does not want to do so.").

${ }^{16} \mathrm{Cf}$. Alasdair MacIntyre, Poetry as Political Philosophy: Notes on Burke and Yeats, in ON MODERn POETRY: Essays Presented to Donald Davie 145, 149 (Vereen Bell \& Laurence Lerner eds., 1988) (arguing that being asked to die for the modern liberal state is "like being asked to die for the telephone company").

${ }^{17}$ KeLSEN \& SCHMITT, supra note 2, at 162.

${ }^{18}$ KeLSEN \& SCHMITT, supra note 2, at 162.

${ }^{19}$ KeLSEN \& SCHMITT, supra note 2, at 162, 164.

${ }^{20}$ KeLSEN \& SCHMITT, supra note 2, at 167.

${ }^{21}$ See, e.g., Lars Vinx, Introduction to Hans Kelsen \& CARL Schmitt, The GuARdian of the Constitution 11-12 (Lars Vinx trans., 2015) ("Schmitt did not mean to suggest that presidential guardianship of the constitution would not be political. Rather, his point is that it would not be party-political.”); DAVID DYZENHAUs, LEGALITY AND LEGITIMACY: CARL SCHMITT, Hans Kelsen, and Hermann Heller In Weimar 77 (1999).

${ }^{22}$ KeLSEN \& SCHMITT, supra note 2, at 162-65.

${ }^{23}$ KeLSEN \& SCHMITT, supra note 2, at 165, 170 ("Judicial independence is only the flip side of the judge's subjection to statute ....”).
} 
completely dependent on norms. ${ }^{25}$ However, the polity's political decision is not determined by already existing constitutional law and thus is quasi-legislative. ${ }^{26}$ For this reason, the political decision - the core of the constitution- "cannot bind the judges in the same way" as a legal norm does. ${ }^{27}$ Giving judges the power of political decision means changing the judiciary's constitutional position. ${ }^{28}$ Schmitt argues that those who designate a judicial institution as the guardian are actually seeking an independent and neutral authority - a mediator - rather than a legal expert. The demand for a constitutional court as the guardian of the polity's core political decision "instrumentalizes" the title "court" as the most well-known, institutionalized form of independence and neutrality. ${ }^{29}$ Following this line of thinking, the constitutional court is meant to act as a mediator rather than a court of law, as there is no law by which to decide existential political issues. By using the title "court," the legitimating power accompanying this word-that stems from judicial expertise in law-is exploited. ${ }^{30}$ Yet, no amount of "judicial procedure could veil the fact" that such a "constitutional court would be a highly political institution"31 that "only appears to be a court."32

The language of existential politics is different from the language of legal expertise. Law as a language of expertise requires systematic rationality while the domain of identity is not always consistent and at times even a-rational. ${ }^{33}$ Decisions on existential identity issues cannot be determined by reference to normative materials and legal expertise. ${ }^{34}$ If the guardian is to protect the polity's identity, it must speak in terms of identity, and not in terms of professional legal expertise. From a legal point of view, decisions on existential identity come as if from nowhere, while the judiciary "is fundamentally nonpolitical, because it is dependent on the general statute." 35 For this reason, responding to challenges to the Weimar Republic on the existential political level would have completely altered and politicized the judicial role. ${ }^{36}$ Rather than merely apply the law (subsumption), judges would have to render highly political decisions and essentially act "as a constitutional legislator" in order to defend the constitution. ${ }^{37}$ Such an act would be "an abuse of the concepts of judicial form and of adjudication" 38 and would essentially transform the court

\footnotetext{
${ }^{24}$ See Kelsen \& SCHMitT, supra note 2, at 87-88, 168.

${ }^{25}$ See Kelsen \& SChmitT, supra note 2, at 108; CARl Schmitt, Constitutional Theory 176, 195, 301 (1928) (Jeffrey Seitzer ed. \& trans., 2008) ("[T]he independence of judges and the strictest bond to the statute condition one another .... This produces a true bond and is not merely a blanket reference too indeterminate norms and to judicial discretion that politicizes the judiciary."). See also Renato Cristi, Carl Schmitt And Authoritarian Liberalism 184 (1998); DYZENHAUS, supra note 21, at 66.

${ }^{26}$ See Lars VinX, Hans Kelsen's Pure Theory of LaW: Legality and Legitimacy 150-51 (2007).

${ }^{27}$ KeLSEN \& SCHMITT, supra note 2, at 165.

${ }^{28}$ See KELSEN \& SCHMITT, supra note 2, at 107.

${ }^{29}$ See KELSEN \& SCHMITT, supra note 2, at 165.

${ }^{30}$ SCHMITT, supra note 25 , at 176 . Schmitt adds that in the most intense political decisions, even mediation is not possible.

${ }^{31}$ KeLSEN \& SCHMiTT, supra note 2, at 168, 171.

${ }^{32}$ SCHMITT, supra note 25, at 389 (“[T]he political conflict cannot be resolved in a judicial procedure.").

${ }^{33}$ See, e.g., KELSEN \& SCHMitT, supra note 2, at 177 (explaining that "[t]he law of non-contradiction" that is part of "the science of law ... has no place in a system of thought whose deep affinity with theology can no longer be overlooked today"); Robert C. Post \& Neil S. Siegel, Theorizing the Law/Politics Distinction: Neutral Principles, Affirmative Action, and the Enduring Legacy of Paul Mishkin, 95 CALIF. L. REV. 1473, 1477-78 (2007) (discussing the values of legal logic and noting that "the goods of consistency, stability, predictability, and transparency ... are essential to the rule of law"); Antonin Scalia, Assorted Canards of Contemporary Legal Analysis, 40 CASE W. RES. L. REV. 581, 588 (1989) ("Consistency is the very foundation of the rule of law.").

${ }^{34}$ Even if Schmitt held a model of judicial expertise more robust than the subsumption model—see SCHEUERMAN, supra note 7 , at 22-24-such expertise cannot answer existential questions.

${ }^{35}$ See SCHMITT, supra note 25, at 229. See also KAHN, supra note 8, at 46-52, 64, 81, 84; DyzENHAUs, supra note 21, at 123; SCHEUERMAN, supra note 7, at 33-34, 45.

${ }^{36}$ See KELSEN \& SCHMITT, supra note 2, at 171 (“[B]e we install a court of justice as the guardian of the constitution, in order to decide highly political questions and conflicts, and before we burden the judiciary with, and endanger it by, such politicization."); SCHMITT, supra note 25, at 164.

${ }^{37}$ See KELSEN \& SCHMITT, supra note 2, at 120.

${ }^{38}$ Kelsen \& Schmitt, supra note 2, at 167. See also JefFrey Seitzer, Comparative History and Legal Theory 89 (2001).
} 
into another political institution. Schmitt summarizes his position in Constitutional Theory, proclaiming that "[e]verything that the judge as judge does is normatively determined and distinguishes itself from the existential character of the political...." 39 Thus, for Schmitt, it was no surprise that the Weimar courts were unwilling and unable to confront identity challenges. ${ }^{40}$

Schmitt accepts judicial review in the limited sense of not applying a statute to the facts when there are "provisions in a constitutional statute" that apply to the same facts. But this preference of "constitutional statutes" over regular statutes does not contradict the notion of the judicial function of "subsumption of a factual situation under a rule." ${ }^{41}$ Even when using this limited authority to review legislation, the judiciary "is bound to the law, and even if it resolves doubts about the validity of a law, it does not abandon the sphere of the purely normative." ${ }^{2}$

In addition to the difficulty of the judiciary deciding issues that are beyond the realm of legality, there is the problem of democratic legitimacy. In the nineteenth century, the judiciary confronted "the monarch's rights to issue decrees, in France as well as in the German constitutional monarchies." 43 But as the "dynastic" source of legitimacy is replaced with "democratic legitimacy," the judiciary is faced with a new reality. ${ }^{44}$ Thus, Schmitt explains that "[t]oday [in the Weimar Republic] the judiciary would no longer be required to set itself against a monarch but rather against the parliament." ${ }^{25}$ Facing a democratically elected institution rather than the monarch means that "from a democratic point of view, it will hardly be possible to transfer such powers to an aristocracy of the robe." 46 The issue is not merely a normative problem of justifying the power of an unelected body reviewing acts of an elected body, ${ }^{47}$ but also a problem in terms of what is "possible." A constitutional court will not be able to stand in the way of an elected parliament. Possessing merely legal expertise, a court cannot defend the political decision against an elected institution. ${ }^{48}$ Thus, although there are connections between a court's normative legitimacy-is its authority justified? - and a court's sociological legitimacy_-does its authority enjoy public support?-Schmitt correctly disentangles the two. The judiciary's authority may be completely justified by a normative analysis conducted in the seminar room and yet still unable to withhold against a popularly elected institution. ${ }^{49}$ In order for the guardian to function effectively, it must be able to act in the name of the people, both in the sense of being able to decide questions regarding their identity and in the sense of having public support to face the elected parliament. As long as its legitimacy is based on expertise, a constitutional court cannot decide in the name of the people and it cannot face the parliament in existential political issues.

\footnotetext{
${ }^{39}$ SCHMiTT, supra note 25, at 300. See also KELSEN \& SCHMITT, supra note 2, at 108 ("In a bourgeois rule-of-law state, adjudication exists only as a court judgment that is based on a statute.").

${ }^{40}$ See KELSEN \& SCHMITT, supra note 2, at 101, 171. For a critique on Schmitt's depiction of judicial decision-making, see SCHEUERMAN, supra note 7, at 181-20 (arguing that Schmitt portrays a caricature of judicial decision-making and then debunks it); Stanley L. Paulson, Hans Kelsen and Carl Schmitt: Growing Discord Culminating in the 'Guardian' Controversy of 1931, in The OXford Handbook OF CARL SCHMitT 510, 525-26 (Jens Meierhenrich \& Oliver Simons eds., 2016) (criticizing Schmitt's position and noting that it contradicts his earlier position that was in line with the free law movement).

${ }^{41}$ KELSEN \& SCHMITT, supra note 2, at 82-89 ("This is not really a denial of the validity of the ordinary statute. It is only a non-application of the ordinary statute to the concrete case at hand that occurs by virtue of an application of the constitutional statute."). See also SCHMITT, supra note 25, at 230-32.

${ }^{42}$ SCHMITT, supra note 25, at 232.

${ }^{43}$ Kelsen \& SCHMitT, supra note 2, at 167-68.

${ }^{44}$ Carl Schmitt, The Crisis of Parliamentary Democracy 30 (Ellen Kennedy trans., 1988) (1926) (“The development from 1815 until 1918 could be depicted as the development of a concept of legitimacy: from dynastic to democratic legitimacy.").

${ }^{45}$ KeLSEN \& SCHMITT, supra note 2, at 168. See also id. at 93-95.

${ }^{46}$ KELSEN \& SCHMITT, supra note 2, at 168.

${ }^{47}$ The normative aspect is emphasized in Dyzenhaus' analysis of Schmitt's position. See DyzENHAus, supra note 21 , at 115.

${ }^{48}$ KELSEN \& SCHMITT, supra note 2, at 135 (explaining that a judiciary is "unable to confront the legislator with anything but indeterminate and controversial principles that could not possibly help to ground an authority superior to the legislator's").

${ }^{49}$ See Or Bassok, The Sociological-Legitimacy Difficulty, 26 J.L. \& PoL. 239 (2011).
} 
According to Schmitt, during the years of the Weimar Republic, the president, elected by the "entire German people" - as stipulated in Article 41 of the Weimar Constitution-enjoyed a unified public confidence as opposed to the parliament's confidence that was split between parties. ${ }^{50}$ In addition, the expression of the people's will by way of a plebiscite was direct, and thus democratically superior, to parliament's votes that only indirectly express the people's will. ${ }^{51}$ For these reasons, Schmitt considered the president as independent and argued that the president can speak in the name of the people's true identity and thus protect the constitution, including against threats from the legislator. ${ }^{52}$ With legitimacy emanating from a plebiscitary type of elections, the president can successfully face the parliament. ${ }^{53}$ Legitimacy based on plebiscites, argued Schmitt, "is the single type of state justification that may be generally acknowledged as valid today." 54

This plebiscitary source of legitimacy "points towards an independence from political parties, but not towards a non-political independence." ${ }^{55}$ In other words, the president is not independent from existential politics, and for this reason, able to defend the polity's political decision.

Kelsen recognizes that he and Schmitt designate different functions for the guardian of the constitution. ${ }^{56}$ One source of this divergence is their different understanding of the role of a constitution. Their different views on the functions of the guardian and the role of the constitution are at the core of their distinct positions on the guardian's source of legitimacy. The best way to approach their distinct positions is by distinguishing between two concepts of constitutional identity. ${ }^{57}$ While Kelsen and Schmitt do not use the term "constitutional identity" themselves, ${ }^{58}$ using it helps to distill the difference between their constitutional models. According to the first understanding of the term constitutional identity, the constitution serves as the focal point of the polity's identity. For example, the US has a constitutional identity in the sense that the US Constitution has been the focal point of American national identity for many years. ${ }^{59}$ This concept

\footnotetext{
${ }^{50}$ See SCHMITT, supra note 25, at 370 ("The president by contrast, has the confidence of the entire people not mediated by the medium of a parliament splintered into parties. This confidence, rather is directly untied in his person.").

${ }^{51}$ See CARL SchmitT, Legality AND Legitimacy 60-61 (Jeffrey Seitzer trans., 2004) (noting that according to Rousseau, "the democratic consequence is that the popular assembly must always recede into the background, if opposed by the people it represents" and that "the referendum is always a higher form of decision").

${ }^{52}$ See KELSEN \& SCHMITT, supra note 2, at 171-72 ("The President of the Reich is elected by the whole German people, and his political competences as against the legislative institution . .. are, in substance, nothing but an 'appeal to the people.").

${ }^{53}$ See KeLSEN \& SCHMITT, supra note 2, at 162 (“[A] president of the Reich who stands on a plebiscitary basis ...”); SchmitT, supra note 51, at 65 ("[I]t is doubtful that the Reichstag could dare to take up battle with the people."). Schmitt's theory is counter-majoritarian only in the sense of resistance to parliamentary majorities. It is hardly countermajoritarian in the sense of resisting the people's will. Cf. Lars Vinx, Carl Schmitt and the Problem of Constitutional Guardianship, in The Contemporary Relevance of Carl Schmitt: Law, Politics, Theology 34 (Matilda Arvidsson, Leila Brännström \& Panu Minkkinen eds., 2016) (“Carl Schmitt's constitutional theory argues for strong counter-majoritarian constraints on the power of legislative majorities.").

${ }^{54}$ SCHMitT, supra note 51 , at 90.

${ }^{55}$ KELSEN \& SCHMITT, supra note 2, at 169.

${ }^{56}$ See KeLSEN \& SCHMITT, supra note 2, at 213-14, 217.

${ }^{57}$ See Or Bassok, Interpretative Theories as Roadmaps to Constitutional Identity: The Case of the United States, 4 GLOBAL Constitutionalism 289, 292-94 (2015) (offering a distinction between two types of constitutional identity).

${ }^{58}$ Monika Polzin argues that Schmitt used the "notion of constitutional identity," yet her evidence for such use is a single quote from Schmitt's Constitutional Theory, where Schmitt writes on "identity and continuity of the constitution as an entirety." Polzin's analysis demonstrates well that reading Schmitt using our current understanding of the concept of constitutional identity is fruitful, but Schmitt did not have this concept in his conceptual tool kit. See Monika Polzin, Constitutional Identity, Unconstitutional Amendments and the Idea of Constituent Power: The Development of the Doctrine of Constitutional Identity in German Constitutional Law, 14 INT'L J. CONST. L. 411, 411-21 (2016).

${ }^{59}$ See, e.g., Hans Kohn, American nationalism: An Interpretive Essay 8 (1957) ("For the American Constitution is unlike any other: it represents the lifeblood of the American nation, its supreme symbol and manifestation.”); Paul W. Kahn, American Exceptionalism, Popular Sovereignty, and the Rule of Law, in AMERICAN EXCEPTIONALISM AND HUMAN RigHTS 198, 206-07 (Michael Ignatieff ed., 2005) ("Only here, does the national political identity focus so clearly and quickly on a legal text.").
} 
of constitutional identity corresponds to Schmitt's understanding of the central role of the constitution. In his view, a political decision-anchored in the constitution-defines the state's identity, its telos. ${ }^{60}$ In this sense, "the state does not have a constitution.... The state is constitution .... The constitution is its 'soul,' its concrete life, and its individual existence." 61

The Schmittian guardian of the constitution protects the polity's identity. Bearing in mind this crucial role, it is now possible to explain why the Schmittian guardian has the power to strike down constitutional amendments that contradict the polity's constitutional identity. The polity's core political decision - "the constitution" in Schmitt's terms - cannot be amended by mere constitutional law. ${ }^{62}$ Due to its role in defining the polity's identity, the core of the constitution and its inviolability must take precedence over the amending procedure. In essence, the political decision is the constitution's eternity clause. ${ }^{63}$ Individual constitutional articles cannot be revised in such a way that violates the constitution's fundamental principles: Constitutional "revision" is not constitutional "annihilation." ${ }^{4}$ Therefore, a constitutional amendment that went through the proper amendment procedure can still be unconstitutional if it is meant to abrogate the polity's political decision. ${ }^{65}$ For similar reasons, in protecting the political decision of the people, the president, as the guardian of the constitution is not limited by legality, only by legitimacy. ${ }^{66}$ "Plebiscitary legitimacy" wins over "legislative legality." 67

According to the second understanding, the term constitutional identity refers to the identity of the constitution itself rather than to the identity of the nation. Every constitution has an identity in the sense of core attributes that form its character. ${ }^{68}$ Having a constitutional identity in this sense does not mean that the focal point of the nation's identity is its constitution. In many nations, the primary function of the constitution is structural or normative while its identity function is minor. ${ }^{69}$ In these nations, the constitution has an identity, but the national identity's focal point is not the constitution. The identities of these nations are rooted elsewhere, in extra-constitutional sources. $^{70}$

\footnotetext{
${ }^{60}$ See SCHMITT, supra note 25, at 59, 65 ("The will of the German people, therefore something existential, established the unity in political and public law terms behind all systematic contradictions, disconnectedness and lack of clarity of the individual constitutional laws."); SСНMITT, supra note 25, at 132 (“[T]he political decision that constitutes the content of the constitution."). See also MCCORMICK, supra note 14, at 230-32, 251.

${ }^{61}$ Schmitt, supra note 25, at 60. See also Andreas Kalyvas, Democracy and the Politics of the Extraordinary: Max Weber, Carl Schmitt, And Hannah AREndt 131 (2008) (“Any founding sovereign decision incorporates some substantive meanings and fundamental principles that account for the identity and eidos of a political community.").

${ }^{62}$ See SCHMITT, supra note 51, at 50-58 (“[E]very constitution recognizes such fundamental 'principles' ... [that are], in principle, unalterable.”); SCHMITT, supra note 25, at 70-73, 150-51. See also DYZENHAUs, supra note 21, at 52-53; KALYVAS, supra note 61, at 141 .

${ }^{63}$ SCHMITT, supra note 25, at 92 (stressing that the political decision is "constant and unchanging ... something absolutely unbreakable").

${ }^{64}$ SCHMITT, supra note 25 , at 151 . See also id. at 72-74, 79-81, 150-58, 215; SCHMITT, supra note 51 , at 58 ("When a constitution envisions the possibility of constitutional revisions, the constitution does not intend to provide, for example, a legal method for the elimination of its own legality, still less the legitimate means to the destruction of its legitimacy.").

${ }^{65}$ See Joseph W. Bendersky, Carl Schmitt: Theorist For The Reich 97-99, 147-48, 197 (1983); Ellen Kennedy, Constitutional Failure: CARL SChmitt in Weimar 172-73 (2004); McCormick, supra note 14, at 234-35, 242; SCHUPMANN, supra note 7 , at 138, 141-42.

${ }^{66}$ See DyzEnHAus, supra note 21 , at 2 (“[T]he legitimate will always assert itself over the legal.”).

${ }^{67}$ SchMiTT, supra note 51 , at 59 .

${ }^{68}$ See Michel Rosenfeld, The Identity of the Constitutional Subject: Selfhood, Citizenship, Culture, And COMMUNiTy 11-12, 113 (2010).

${ }^{69}$ See Dieter Grimm, Integration by Constitution, 3 INT'L. J. CONST. L. 193, 194-96 (2005) (“[T]he constitution is primarily intended to produce normative effects.”); Michel Rosenfeld, The European Treaty-Constitution and Constitutional Identity: A View from America, 3 INT'L. J. Const. L. 316, 323 (2005) (“Constitutional identity, therefore, is much more central to national identity in the United States model than it is in the French or [pre-World War II] German model.”)

${ }^{70}$ See Gary Jeffrey Jacobsohn, Constitutional Identity, 68 REv. Politics 361, 364-65, 368 (2006).
} 
Kelsen does not attribute to the constitution a role in the creation of a shared identity for the people. ${ }^{71}$ In his view, in a pluralist society with disagreements over the question of the good, there should not be one unifying, permanent identity with one particular organ empowered to unilaterally decide in disagreements over this identity. ${ }^{72}$ While Schmitt sees the political substance as allowing the creation of unity to halt the pluralist threat, Kelsen wants-in the name of plurality of views on the community's identity-to preserve the people's ability to revise any legal content. ${ }^{73}$ In Kelsen's view, the state is a normative construct, not an identity bearer. ${ }^{74}$ Contrary to Schmitt's vision, in Kelsen's mind, the state is not a state of substance, and the constitution need not embody such substance. ${ }^{75}$ Kelsen aims to purify legal theory from what he views as non-legal totemistic fictions, such as political substance. ${ }^{76}$ The idea that the constitution expresses a permanent identity of the people that transcends legally organized, pluralist politics is an anathema for Kelsen. ${ }^{77}$ Rather, for Kelsen, the agreement to legal norms and compliance with them by a large part of the public constitute the unity of the state. ${ }^{78}$

While Schmitt did not believe in the judiciary's ability to decide political-existential decisions and wanted to exclude judges from decisions on the substance of the state, Kelsen did not believe the state needed to make these decisions. ${ }^{79}$ For this reason, judges, in Kelsen's vision, should avoid attributing to the constitution a full permanent account of the good life. ${ }^{80}$ The point of democracy is to provide a legal framework that allows peaceful changes in the polity's way of life. ${ }^{81}$ The role of Kelsen's guardian is to protect the identity of the constitution rather than the identity of the polity. ${ }^{82}$ This position led Kelsen to reject many of the functions that Schmitt viewed as part of the guardian's role. ${ }^{83}$ For example, Kelsen accepted that a provision in the constitution can declare itself unamendable. However, his constitutional model lacked a political decision that stands at the core of the constitution and allows the guardian to review constitutional amendments even if they were enacted according to the proper procedure. ${ }^{84}$ Kelsen did not construct a substantive concept that would restrict the legislative authority. He opposed the idea that a constitutional court could strike down laws based on declarations of purpose located in preambles.

\footnotetext{
${ }^{71}$ Hans Kelsen, Introduction to the Problems of Legal Theory 99-106 (Bonnie Litschewski Paulson \& Stanley L. Paulsen trans., 1992) (1934). See also Peter C. Caldwell, Popular sovereignty and the Crisis of German Constitutional Law: The Theory \& Practice of Weimar Constitutionalism 49, 90 (1997) ("Kelsen implicitly viewed state and law as identical ....").

${ }^{72}$ See VINX, supra note 26 , at 170.

${ }^{73}$ See Kelsen, supra note 71, at 31-32, 98. See also VINX, supra note 26, at 142.

${ }^{74}$ See Hans Kelsen, The Essence and Value of Democracy 35-42 (Brian Graf trans., 2005) (1920); Kelsen, supra note 71, at 99-100 (“The state, then, is a legal system."), 105 (“[E]very state is only a legal system ....”). See also CALDWELL, supra note 71, at 49 ("Kelsen implicitly viewed state and law as identical ...."); JoHn H. Hallowell, The Decline Of Liberalism AS AN IDEOLOGY 97-98 (1946) (“The state is identified by Kelsen with the legal order ....").

${ }^{75}$ See Nicolleta Ladavac, Philosophy of Law and Theory of Law: "The Continuity of Kelsen's Years on America", in Hans Kelsen in America: Selective Affinities and the Mysteries of ACAdemic Influence 229, 242 (D.A. Jeremy Telman ed., 2016).

${ }^{76}$ See KeLSEN, supra note 71, at 31-32, 98. See also CALDWELL, supra note 71, at 119.

${ }^{77}$ See VINX, supra note 26, at 126, 132.

${ }^{78}$ See Manfred Baldus, Hapsburgian Multiethnicity and the "Unity of the State" - On the Structural Setting of Kelsen's Legal Thought, in Hans Kelsen and Carl Schmitt: A Juxtaposition 13, $20-21$ (Dan Diner \& Michael Stolleis eds., 1999); CALDWELL, supra note 71, at 113.

${ }^{79}$ See Raphael Gross, "Jewish Law and Christian Grace" - Carl Schmitt's Critique of Hans Kelsen, in HANS KELSEN AND CARL SCHMitT: A JuXTAPOSITION, supra note 78, 101, at 103.

${ }^{80}$ See VINX, supra note 26 , at 171.

${ }^{81}$ See VINX, supra note 26, at 132-33.

${ }^{82}$ See KELSEN \& SCHMITT, supra note 2, at 174 (“'Guardian of the constitution': in its original sense, this term refers to an organ whose function it is to protect the constitution against violation.").

${ }^{83}$ See KeLSEN \& SCHMITT, supra note 2, at 213-14.

${ }^{84}$ See Claude Klein, "The Eternal Constitution" - Contrasting Hans Kelsen and Carl Schmitt, in HANS KELSEN AND CARL SCHMitT: A JuXTAPOSITION, supra note 78, 61, at 63-64.
} 
In his view, the legislator is only limited by explicit constitutional norms. ${ }^{85}$ The guardian's role is merely to protect the constitution from violations of these norms.

Kelsen writes that the constitution is the "rule that determines the genesis of statutes." 86 The Kelsenian guardian's role is to apply constitutional norms - that are mostly focused on procedural requirements - to the process of creating statutes. ${ }^{87}$ Just as "regular" courts require administrative acts to be in accordance with statutes in order for the acts to be legal, the constitutional court merely enforces the principle of legality when it requires legislative acts to be in accordance with the constitution. ${ }^{88}$ Because the constitutional court is mainly interested in whether the creation of statutes is in accordance with the legislative procedure proscribed in the constitution, it essentially applies law to facts - the facts being the process of legislation-in its judicial review process. ${ }^{89}$ "And precisely in this respect," writes Kelsen, "its function resembles that of courts in general; it is mostly application of law, and thus it is in this sense, true adjudication." $" 90$

Based on the view that the chief role of a constitution is regulating the procedure for the creation of statutes, Kelsen depicts constitutional articles that go beyond this role as "clothing" nonconstitutional material in constitutional form. ${ }^{91}$ Only constitutional provisions that have a meaning that is easy to determine can serve as the basis for the invalidation of a piece of legislation based on its content. ${ }^{92}$ Reviewing the legality of legislation based on "vague slogans like 'freedom', 'equality', 'justice', and so forth" would create "a danger of a politically highly inappropriate shift of power ...." ${ }^{\prime 3}$ Kelsen adds that if judges rely on an "ill-defined and highly ambiguous word like "justice" to review legislation, their decisions would reflect "the free discretion of a college whose members are ... arbitrarily chosen, from a political point of view," 94 rather than their expertise in law. ${ }^{95}$ Kelsen views the constitutional court as a negative legislator because its decisions to annul legislation affect general norms. ${ }^{96} \mathrm{He}$ does not, however, see it as a regular legislator, in part

\footnotetext{
${ }^{85}$ See VINX, supra note 26 , at $125-26$.

${ }^{86} \mathrm{KeLSEN} \&$ SCHMITT, supra note 2, at 28. See also KeLSEN, supra note 71, at 63-64.

${ }^{87}$ KeLSEN \& SCHMITT, supra note 2, at 176 ("The point is simply that a norms is to be annulled for the individual case or generally, because its creation stands in contradiction to a higher norm that is higher precisely because it regulates its creation.").

${ }^{88}$ See KELSEN \& SCHMITT, supra note 2, at 45 (“[T] he demand that statutes be constitutional, therefore, does not differ, from a legal-theoretical and legal-technical point of view, from the demand that jurisdiction and administration conform to statute.").

${ }^{89}$ See KELSEN \& SCHMITT, supra note 2, at 188 ("The 'matter of fact' that is to be subsumed under the constitutional norm in the case of a decision on the constitutionality of a statute is not a norm-fact and norm are different concepts-but rather the creation of the norm. And the creation of a norm is a genuine 'matter of fact' regulated by the constitutional norm.").

${ }^{90}$ KeLSEN \& SCHMITT, supra note 2, at 47. In an attempt to deny Schmitt's argument that the guardian cannot be a court because the guardian's functions contradict the judicial function, Kelsen accused Schmitt of being bound to "conceptual jurisprudence." In other words, Kelsen denied that the guardian must be classified as a "court." Yet, Kelsen hardly denied that the institutional characteristics of the guardian would be similar to those of a judicial institution. See KELSEN \& SCHMITT, supra note 2, at 181-83.

${ }^{91}$ See KELSEN \& SCHMITT, supra note 2, at 31, 73 ("From a legal-technical point of view, the constitution ... determine[s] the procedure of legislation and provide[s] certain guidelines for the content of statutes ...."); KeLSEN, supra note 71, at 64 .

${ }^{92}$ See KELSEN \& SCHMITT, supra note 2, at 60-61 (stating that judicial review of statutes on the ground of general formulations such as "justice," "would concede to the constitutional court a fullness of power that must be regarded as altogether intolerable"). See also Vinx, supra note 26, at 164.

${ }^{93}$ KeLSEN \& SCHMITT, supra note 2, at 193.

${ }^{94}$ KELSEN \& SCHMITT, supra note 2, at 61 ("Such a shift of power from parliament to an extra-parliamentary institution, one that may turn into the exponent of political forces completely different from those that express themselves in parliament, is certainly not intended by the constitution and highly inappropriate politically.").

${ }^{95}$ See Dyzenhaus, supra note 21, at 152 (explaining that according to Kelsen, "one needs the content of the constitution to be specified by the constitution with sufficient precision to limit severely judicial discretion in evaluating legislation for constitutionality.").

${ }^{96}$ See Hans Kelsen, Judicial Review of Legislation: A Comparative Study of the Austrian and the American Constitution, $4 \mathrm{~J}$. Politics 183, 187 (1942).
} 
because its decisions are not based on will. Rather, even though it is a constitutional court, it still makes its decisions based on legal reason, as courts do. ${ }^{97}$

Kelsen's position on the role of the constitutional court as the guardian is tightly connected to his theory on the hierarchy of legal norms. ${ }^{98} \mathrm{~A}$ formal constitution, as the law governing the genesis of ordinary legislation, is a defective form of law unless ordinary legislation is required to conform to it. ${ }^{99}$ Kelsen views judicial review by a constitutional court as necessary to guard the conformity of lower level norms to those at a higher level of the legal order. ${ }^{100} \mathrm{He}$ calls this systematic trait: legality. ${ }^{101}$ The best guarantee for constitutional legality is a constitutional court endowed with the power to annul unconstitutional legislation. ${ }^{102}$ Judicial review provides a guarantee of legality necessary for the preservation of the system. ${ }^{103}$ Democracy will break down, according to Kelsen, without "institutional controls" ensuring constitutional legality. ${ }^{104}$

Thus, one of the guardian's obligations, according to Kelsen, is to ensure internal systematic coherence and consistency between superior constitutional norms and inferior regular legislation. ${ }^{105}$ For Kelsen, the consistency within the legal system and its internal cohesion are central to conceiving law as a scientific endeavor. ${ }^{106}$ Based on his view of the guardian's role in protecting the systematic logic of constitutional law as law_or in his terms, "legality"-Kelsen claims that the constitutional court needs to be composed of legal experts. ${ }^{107}$ In other words, the Kelsenian guardian's source of legitimacy stems from legality as a field of expertise. ${ }^{108}$

While Kelsen puts more emphasis on the constitution's "essential function" of determining the "process of general law creation," 109 he does not deny that the constitution aims, at times, to "determine the content of future statutes" by proscribing or precluding certain content. ${ }^{110}$ In his view, by demanding strict adherence to the constraints of constitutional legality in the process of legislating, the guardian may be able to protect more than just the proper procedure of legislation. For example, Kelsen argues that the ability to amend the constitution with regard to

\footnotetext{
${ }^{97}$ See Michel Troper, “The Guardian of the Constitution" - Hans Kelsen's Evaluation of a Legal Concept, in HANS KELSEN AND CARL SCHMitT: A JuXTAPOSITION, supra note 78, 81, at 92-93.

${ }^{98} \mathrm{See}$ KELSEN, supra note 71, at 63-65 (explaining the superiority of the constitution as part of " $\mathrm{t}$ ] he hierarchical structure of the legal system" and the mechanisms to enforce it); KELSEN \& SCHMITT, supra note 2, at 45.

${ }^{99}$ See KELSEN \& SCHMitT, supra note 2, at 27-28 ("It is the rule that determines the genesis of statutes."); KELSEN \& SCHMITT, supra note 2, at 69 ("As long as a constitution lacks the guarantee, presented in the foregoing of the annullability of unconstitutional acts it also lacks the character of full legal bindingness in the technical sense."). See also VINX, supra note 26 , at 146 .

${ }^{100}$ See KeLSEN \& SCHMITT, supra note 2, at 56 ("Put in general terms, all acts must be reviewed or their conformity with the relevant higher-level norms."); KELSEN \& SCHMITT, supra note 2, at 189 (“The point is simply that a norm is to be annulled for the individual case or generally, because its creation stands in contradiction to a higher norm that is higher precisely because it regulates its creation."). But see KELSEN, supra note 71, at 71-73 (explaining that a contradiction between a law and the constitution can exist; the law contradicting the constitution is to be considered as deficient rather than as unconstitutional or illegal).

${ }^{101}$ See KeLSEN \& SCHMITT, supra note 2, at 24-27. See also VINX, supra note 26, at 145, 160.

${ }^{102}$ See KeLSEN \& SCHMITT, supra note 2, at 69-71. See also Vinx, supra note 21, at 8; Michel Troper, Marshall, Kelsen, Barak and the Constitutionalist Fallacy, 3 INT'L. J. CONST. L. 24, 30 (2005).

${ }^{103}$ See Kelsen \& SCHMitT, supra note 2, at 251. See also Vinx, supra note 26, at 146-47.

${ }^{104}$ See KeLSEN, supra note 74 , at 83.

${ }^{105}$ See Troper, supra note 97 , at 81,86 .

${ }^{106}$ See KelSEN, supra note 71, at 53. See also Baldus, supra note 71, at 16.

${ }^{107}$ See KELSEN \& SCHMITT, supra note 2, at 76 ("With regard to the composition of the constitutional court, which is formed as a collegial organ, one has to take care, above all, to eliminate party-political influence and to attract legal expertise, in particular in constitutional law.").

${ }^{108}$ See KELSEN \& SCHMITT, supra note 2, at 31, 47-48 (“[T]he court is going to have to perform the purely juristic work of constitutional interpretation .... It is of the utmost importance that legal experts be given due consideration in the composition of the court .... The court itself has the greatest interest in strengthening its authority through the admission of outstanding experts ...."). See also VINX, supra note 26, at 162 .

${ }^{109}$ KeLSEN, supra note 71 , at 64-66.

${ }^{110} \mathrm{KeLSEN}$, supra note 71 , at $64-65$.
} 
fundamental issues usually depends on achieving "heightened majority," which requires minority participation. In this way, the majority has to compromise with the minority. By ensuring that the majority can achieve its goals only by adhering to these types of procedural limitations proscribed by the constitution, the guardian protects minorities "against assaults on the part of the majority."111

According to Kelsen, a formal constitution is only meaningful and effective if protected by a constitutional court that ensures legality. ${ }^{112}$ If there is no guarantee for such constitutional legality, then the constitution would lack full, legally binding force. ${ }^{113}$ And because a constitutional court is required by this systematic logic of constitutional law, there are no jurisprudential reasons against introducing constitutional adjudication into a constitutional system, only political ones. No wonder, then, that he viewed Schmitt's arguments as abusing legal science. ${ }^{114}$

Kelsen responds to Schmitt's argument on the constitutional court's inability to harness public support as its source of legitimacy by stating " $[\mathrm{t}]$ here is no obstacle to have judges elected by the people, just like the head of state, if one wants to design the constitutional court in democratic fashion." 115 However, Kelsen argues that it is doubtful whether such a court would be able to remain neutral. Kelsen writes that "[t]o regard election as a guarantee of independence ... is possible only if one closes one's eyes to reality." 116 In this vein, Kelsen emphasizes that it is unlikely that a president elected by the majority in a process determined by pressures of party politics would be detached from partisan conflict of interests. ${ }^{117} \mathrm{~A}$ court whose members are selected by parliament, rather than by the public, is more likely to produce such neutrality as "a judge is automatically driven towards neutrality by the ethos of his profession." 118 Additionally, since the judiciary is an independent party, detached from the parties participating in the process of legislation, as an independent party it can assure that "no one [is] the judge in his own cause." 119 As for the claim that courts are acting against popular sovereignty by thwarting the will of the legislator, Kelsen stresses that popular sovereignty does not reside in one organ of the state. Rather, it is an attribute of the legal regime as a whole and not of any particular institution within it. ${ }^{120}$ For this reason, he rejects Schmitt's claim that the president represents the will of the people. $^{121}$

Except in the realm of existential politics, Kelsen had good replies to Schmitt with regards to analyzing the relationship between law and politics. In terms of partisan politics, Kelsen argued that constitutional courts are relative outsiders of the political arena in comparison to elected institutions. ${ }^{122} \mathrm{He}$ did not deny that courts are political institutions in the sense that they "exercise

\footnotetext{
${ }^{111}$ Kelsen \& SCHMitT, supra note 2, at 71. See also KelSEN, supra note 74, at 83; VINX, supra note 26, at 126-28.

${ }^{112}$ See Kelsen \& SCHMITT, supra note 2, at 216 (arguing that the "function of a 'guardian of a constitution,' [is] that of control over the constitutionality of acts of state").

${ }^{113}$ See KeLSEN \& SCHMiTT, supra note 2, at 251. See also VINX, supra note 26, at 160.

${ }^{114}$ See KELSEN \& SCHMiTT, supra note 2, at 45, 190-91 ("[T] adjudication is incompatible with the sovereignty of the legislator .... One might, under certain circumstances hold such absence of restriction to be desirable; but such a standpoint cannot be defended by juristic arguments."). See also VINX, supra note 26, at 162-63; DYZENHAUs, supra note 21, at 122 (presenting the duality in Kelsen's position that at times argues that "the issue whether or not one should have a constitutional court with the right to test the validity of legislation is a political one, and thus not a fit subject for legal science"); DYZENHAUs, supra note 21, at 153 (according to Kelsen, an attack on the principle of legality, or any of its technical components, "violates the requirement that science should be kept distinct from ethics and politics").

${ }^{115}$ KeLSEN \& SCHMITT, supra note 2, at 215.

${ }^{116}$ KeLSEN \& SCHMITT, supra note 2, at 209.

${ }^{117}$ See KelSEN \& SCHMitT, supra note 2, at 209; CALDWELL, supra note 71, at 115.

${ }^{118}$ KELSEN \& SCHMITT, supra note 2, at 210.

${ }^{119}$ Kelsen \& SChmitT, supra note 2, at 175. See also Dyzenhaus, supra note 21 , at $115,118,152$.

${ }^{120}$ See Dyzenhaus, supra note 21 , at $115-16$; VINX, supra note 26 , at 82.

${ }^{121}$ See CALDWELL, supra note 71 , at 9.

${ }^{122}$ Kelsen \& SChMitT, supra note 2, at 203-04. See also Dyzenhaus, supra note 21, at 119.
} 
power" or have discretion in applying the law. ${ }^{123}$ Kelsen accepted that the courts confront issues of high politics—-for example, "conflict of interest or power." ${ }^{124}$ He attacked Schmitt's presentation of judicial decision-making as mere "subsumption," admitting that "there is only a quantitative but not a qualitative difference between the political character of legislation and adjudication." 125 According to Kelsen, the view that the law has a fixed certain meaning that needs to be discovered through interpretation is a mere illusion. Judges create law. ${ }^{126}$ Still, Kelsen insisted that courts exercise a different function than the elected branches. Judges are more bound by their legal expertise and more independent of partisan pressure than the elected branches. ${ }^{127}$

Nevertheless, Kelsen failed to confront Schmitt's claim regarding the inability of courts to decide political-identity questions without losing their neutrality and without straying from their commitment to decide according to legal criteria. Schmitt's argument focused on the most intense and foundational level of politics: Identity politics. On the face of the text, Kelsen seems to misunderstand Schmitt's use of the term "political." He argued that Schmitt contradicts himself by proclaiming in one place that judicial decisions are inherently political while proclaiming in other places that they need to be apolitical. ${ }^{128}$ Yet, as explained above, Schmitt used the term "political" to designate different meanings. Schmitt objected to judicial decisions being political in the sense of partisan politics; however, at the same time, he accepted that they are political in the sense of deciding discretionary policy issues. He also believed that judicial decisions cannot be political in the sense of stating or deciding the existential identity of the polity. It is highly likely that Kelsen understood well what Schmitt meant ${ }^{129}$ and just wanted to "muddy the waters"; by conflating the meanings of "political," he ensured that Schmitt's argument would be rhetorically defeated without answering the challenge Schmitt presented regarding courts dealing with existential politics. ${ }^{130}$

\section{The American Supreme Court and the Shift in Understanding Judicial Legitimacy}

In recent decades, several national high courts have shifted their understanding of judicial legitimacy. It began in the US. As I have shown in previous work, ${ }^{131}$ today, there is an almost total consensus among American judges and scholars that, because the Supreme Court (hereinafter: the Court) lacks direct control over either the "sword or the purse," enduring public support is necessary for the Court's proper function. ${ }^{132}$ Judicial legitimacy is thus commonly understood in terms of public support. ${ }^{133}$

\footnotetext{
${ }^{123}$ See KeLSEN \& SCHMITT, supra note 2, at 183-84, 189-90. See also DyZENHAUs, supra note 21, at 112-13.

${ }^{124}$ KELSEN \& SCHMITT, supra note 2, at 184 ("After all, every conflict of right is also a conflict of interest or power, every legal dispute therefore a political dispute.").

${ }^{125}$ KelSEN \& SCHMITT, supra note 2, at 184-85. See also CALDWELL, supra note 71, at 111.

${ }^{126}$ KeLSEN, supra note 71 , at 82-84.

${ }^{127}$ See KeLSEN \& SCHMitT, supra note 2, at 210-11; KeLSEN, supra note 71, at 83.

${ }^{128}$ See KeLSEN \& SCHMITT, supra note 2, at 190-91.

${ }^{129}$ Kelsen wrote that according to Schmitt, "[t]he constitution is not made up of norms or 'statues' at all. 'Constitution,' rather, is a status, the condition of 'unity' of the German people.” KELSEN \& SCHMITT, supra note 2, at 218.

${ }^{130}$ See KelSEN \& SCHMiTT, supra note 2, at 183 (discussing the difficulty to decipher the meaning of the term "political" and noting that it is an "ambiguous and abused word").

${ }^{131}$ See, e.g., Or Bassok, The Supreme Court's New Source of Legitimacy, 16 U. PA. J. Const. L. 153, 156 (2013).

${ }^{132}$ See, e.g., Planned Parenthood v. Casey, 505 U.S. 833, 865 (1992) (plurality opinion) (“The Court's power lies, rather, in its legitimacy, a product of substance and perception that shows itself in the people's acceptance of the Judiciary ....”); STEPHEN Breyer, Making Our Democracy Work: A Judge's View, at xiii (2010) ("The Court itself must help maintain the public's trust in the Court"); Barry Friedman, The Birth of an Academic Obsession: The History of the Countermajoritarian Difficulty, Part Five, 112 YALE L.J. 153, 221 (2002) ("[M]any commentators made the point that judicial power ultimately depended upon popular acceptance.").

${ }^{133}$ For example, Jeffery Rosen argues that the Court has a legitimacy problem based on "a New York Times/CBS poll [that] found that only 44 percent of Americans approve of the Supreme Court's job performance." See Jeffery Rosen, The Supreme Court Has a Legitimacy Crisis, But Not for the Reason You Think, New RePUBLIC (June 11, 2012), https://newrepublic.com/ article/103987/the-supreme-court-has-legitimacy-crisis-not-the-reason-you-think.
} 
This was not always the prevailing understanding. Alexander Hamilton wrote in The Federalist No. 78 that " $[\mathrm{t}]$ he judiciary on the contrary has no influence over either the sword or the purse .... It may truly be said to have neither Force nor Will, but merely judgment ...."134 Hamilton-who spoke in The Federalist No. 78 on judges "as faithful guardians of the Constitution"135 long before Schmitt and Kelsen—viewed the Court's legitimacy as based "merely" on its judicial expertise, not on public support for the Court. ${ }^{136}$ Tracking the manner in which Hamilton's dictum has been read by the Court and scholars over the years is one technique I use in previous work to demonstrate the shift in understanding judicial legitimacy in the US. ${ }^{137}$ As this very famous dictum has served over the years as the starting point for discussions on the Court's legitimacy, it is plausible to assume that a change in understanding judicial legitimacy will be reflected in the way in which it is discussed and understood. In addition, by tracking the changing understanding of this famous dictum, I can avoid accusations that I am cherry picking quotes that fit my argument.

A few recent examples will suffice to illustrate the shift. In Williams-Yulee v. Fla. Bar, ${ }^{138}$ Chief Justice Roberts began his judgment by quoting The Federalist No. 78, stating that "[u]nlike the executive or the legislature, the judiciary "has no influence over either the sword or the purse; ... neither force nor will but merely judgment." Yet after this accurate quote of Hamilton's dictum, Roberts proceeded by writing that " $\mathrm{t}]$ he judiciary's authority therefore depends in large measure on the public's willingness to respect and follow its decisions." ${ }^{39}$ While Chief Justice Roberts formulated his second sentence as if it was deduced from Hamilton's dictum ("therefore"), ${ }^{140}$ his position is very different than the one Hamilton presented. There are several differences, but I will focus on two prominent ones. First, according to Hamilton's picture, the judiciary's reliance on its "judgment" means that if it possesses expertise, its decisions would be followed by the executive even if it lacks public support. In the picture Roberts presented, expertise without public support has little value for the Court's authority. Second, according to Roberts' picture, even if the judiciary lacks expertise, the executive will follow its decisions if it possesses public support.

Roberts' approach is shared by his progressive brethren. In 2002, Justice Ruth Bader Ginsburg wrote in Republican Party of Minnesota $v$. White that "[b]ecause courts control neither the purse nor the sword, their authority ultimately rests on public faith in those who don the robe." ${ }^{141}$ In his book, Making Our Democracy Work - A Judge's View, Justice Stephen Breyer stated that "[t]he Court itself must help maintain the public's trust in the Court" in order to ensure its proper function. ${ }^{142}$ This position was one of the premises of Justice Breyer's dissenting opinion in Bush v. Gore. ${ }^{143}$ Breyer explained that "the appearance of a split decision" in such a "highly politicized matter" will undermine "the public's confidence in the Court itself."144 "That confidence," he further wrote, "is a public treasure. It has been built slowly over many years .... It is a vitally

\footnotetext{
${ }^{134}$ Hamilton, supra note 1 , at 392.

${ }^{135}$ Hamilton, supra note 1 , at 392.

${ }^{136}$ See Or Bassok, The Supreme Court at the Bar of Public Opinion Polls, 23 Constellations 573, 574-75 (2016); PAUL O. Carrese, The Cloaking of Power: Montesquieu, Blackstone, And the Rise of Judicial Activism 208 (2010) (arguing that Hamilton's account of the judiciary, "praises judges who are not strictly republican, since their source of authority is not solely the consent of the people .... Hamilton's defense of judicial review ... emphasizing not only the judiciary's weakness but also the training and character of judges").

${ }^{137}$ BAssoK, supra note 136.

${ }^{138}$ Williams-Yulee v. Fla. Bar, 135 S. Ct. 1656 (2015).

${ }^{139} \mathrm{Id}$. at 1666.

${ }^{140}$ See also id. at 1672-73 to Roberts's judgment where he concludes that Hamilton's position was aimed to maintain the public's respect in the judiciary. See also Obergefell v. Hodges, 135 S. Ct. 2584, 2611 (2015) (Roberts, C.J., dissenting).

${ }^{141}$ Republican Party of Minn. v. White, 536 U.S. 765, 817-18 (2002).

${ }^{142}$ Stephen Breyer, Making our Democracy Work : A Judge's View xiii (2010).

${ }^{143}$ Bush v. Gore, 531 U.S. 98 (2000).

${ }^{144} I d$. at 157 (Breyer, J., dissenting).
} 
necessary ingredient of any successful effort to protect basic liberty and, indeed, the rule of law itself." 145

Scholars have also paraphrased Hamilton's dictum from The Federalist No. 78 to fit the current controlling understanding. Luis Fuentes-Rohwer's recent article "Taking Judicial Legitimacy Seriously" is a good example. ${ }^{146}$ Funentes-Rohwer equates judicial legitimacy with "acceptance of the Court as a constitutional branch, measured by public opinion polls". ${ }^{147}$ In discussing judicial concerns for the Court's public support, he refers to several examples from various judgments. He then notes that "[t]he argument traces as far back as 1788" and quotes Hamilton's dictum from The Federalist No. $78 .{ }^{148}$ Yet, before the 1930s and the invention of public opinion polls, one could not think of judicial legitimacy in terms of measurable public support. This fact does not prevent Fuentes-Rohwer from presenting an uninterrupted continuity between Hamilton's conception of judicial legitimacy and the current dominant paradigm that equates judicial legitimacy with the results of public opinion polling.

Until the 1930s and the invention of public opinion polls, elected representatives had a monopoly on the claim to legitimacy based on public support. ${ }^{149}$ Before 1930, besides elections, no other source of data could give direct, regular, and reliable measurements of what the public was thinking. ${ }^{150}$ A tacit understanding, based on published public opinion polls, that the Court enjoys higher levels of public support than elected branches could not exist. Without public proof that allows the Court's legitimacy to be understood in terms of public support, it should not come as a surprise that, between the 1880s and the 1930s, the Court's legitimacy was generally understood in terms of expertise. ${ }^{151}$ The political branches that obeyed the Court did so-even if it lacked public support-like a patient following a doctor's advice.

If some readers perceive this idea as bizarre, just think of central banks. In the US, the Federal Reserve was designed as an institution that offers judgments in its realm of economic expertise and is unaccountable to the public. ${ }^{152}$ No regular measurements of public support of the Federal Reserve are conducted, and at least until the 2008 financial crisis, the scholarly debate on the counter-majoritarian nature of the Fed's function was still quite scarce. ${ }^{153}$ The dominant understanding for many years has been that, as part of the American system of governance, the Federal Reserve relies on the regime's democratic legitimacy, but it does not require public support as a separate institution. The Court was in a similar situation for many years.

The concept of public opinion-in its modern sense as the collective voice of the popular will-had already made an appearance in the eighteenth century, long before the invention of

\footnotetext{
${ }^{145} \mathrm{Id}$. at $157-58$ (Breyer, J., dissenting).

${ }^{146}$ Luis Fuentes-Rohwer, Taking Judicial Legitimacy Seriously, 93 CHI.-Kent L. Rev. 505 (2018).

${ }^{147} I d$. at 507 .

${ }^{148} I d$. at 506. See also id. at 508 (quoting Frankfurter's line from Baker v. Carr, noting that "[t] $]$ his is an old admonition. Publius told us as much while defending the virtues of the judiciary" and then quoting Hamilton's dictum from The Federalist No. 78).

${ }^{149}$ See, e.g., Bassok, supra note 131, at 156; Amy Fried \& Douglas B. Harris, Governing with the Polls, 72 HISTORIAN 321,341 (2010) (explaining that until the invention of public opinion polls, Congress was public opinion).

${ }^{150}$ See Robert S. Erikson, Norman R. Luttbeg \& Kent L. Tedin, AmERICAN Public Opinion: Its Origins, ConTEnT AND IMPACT 23 (2d ed. 1980).

${ }^{151}$ See Bassok, supra note 131, at 167-68.

${ }^{152}$ See, e.g., John T. Woolley, Monetary Politics: The Federal Reserve and the Politics of Monetary Policy 88 (1986) ("The Federal Reserve depends on expertise, and economists are the relevant experts.").

${ }^{153}$ See Frederick Schauer, The Supreme Court, 2005 Term - Foreword: The Court's Agenda - and the Nation's, 120 HARV. L. REV. 4, 54-55 (2006) (claiming that there is almost no discussion of the counter-majoritarian difficulty with regard to the Federal Reserve Board partly because "many people believe, rightly or wrongly, that most agency decisions are based on technical knowledge which neither the people nor their directly elected representatives possess.").
} 
opinion polling. ${ }^{154}$ Therefore, it is not surprising that many years before the rise of the "public opinion culture," 155 the Court and scholars spoke occasionally of the Court's reliance on public confidence. ${ }^{156}$ However, until the 1930 s there was no viable tool for measuring it (except on election-day). For this reason, before the rise of opinion polling, saying that the Court relied on public confidence usually expressed a normative assessment or an atmosphere of support. On other occasions, reference to "public confidence" was used to point out the consent of the public to the regime as a whole (rather than support for the Court as an individual institution), which endows the Court with democratic legitimacy. ${ }^{157}$ In this spirit, Owen Fiss explained that in a democracy, "consent is not granted separately to individual institutions. It extends to the system of governance as a whole. Although the legitimacy of the system depends on the people's consent, an institution within the system does not depend on popular consent." ${ }^{158}$ Unsurprisingly, as noted above, this position was already present in Kelsen's writing.

The invention of opinion polls in the 1930s was followed, since the 1960s, by regular measurement of public support for the Court. The ability to track public support for the Court, the public record of this support - often published by popular media—and the scientific allure of opinion polls made public support in the Court more "real" in the public imagination. It became possible, for the first time in history, to view the Court's legitimacy in terms of public support. Based on these developments, a new understanding has emerged according to which the Court requires public support to function properly. ${ }^{159}$

The shift I describe in how judicial legitimacy has been understood in the US in recent years would hardly be foreign to Schmitt. In Political Theology, Schmitt speaks of two detrimental moments in the theory of the state that occurred in the nineteenth century. The second was the formation of a new concept of legitimacy, "which means that the democratic notion of legitimacy has replaced the monarchical .... Royalism is no longer because there are no kings." 160 The source of legitimacy changed from a theological, undiscussed sacred foundation to popular sovereignty. ${ }^{161}$ Not only had the idea of legitimacy shifted, but the way in which it was assessed transformed from a qualitative criterion into a "quantitative determination" as well. ${ }^{162}$ A similar development is now underway with courts whose legitimacy is now understood in terms of measurable public support, rather than in terms of expertise. If this shift would succeed, a Schmittian may argue in a few decades that there are no supreme courts or constitutional courts, not because there is no institution called "the Supreme Court" (Schmitt spoke of "no kings" at a time when there were still rulers called "kings"). Rather, this statement would be based on a drastic shift in the logic of courts due to the change of their source of legitimacy that would make them stop functioning as courts.

The analogy to Schmitt's discussion of royalism exposes another delicate point. The shift in understanding judicial legitimacy does not mean that the Court follows public opinion. After the shift in understanding royalism's source of legitimacy, kings did not necessarily follow public

\footnotetext{
${ }^{154}$ John Durham Peters, Historical Tensions in the Concept of Public Opinion, in PUBLIC OpINION AND THE Communication of Consent 3, 9, 11-14 (Theodore L. Glasser \& Charles T. Salmon eds., 1995) ("Public opinion is, first of all, an 18th-century invention, not an eternal given of human life."); John Durham Peters, Realism in Social Representation and the Fate of the Public, in Public Opinion And Democracy: Vox Populi-Vox Dei 85, 86 (Slavko Splichal ed., 2001) ("The idea of a public realm of citizens or a sociological aggregate - 'the public' - did not exist until the eighteenth century ....”).

${ }^{155}$ Public opinion culture is a culture in which almost every public issue is polled, and the media devotes attention to poll results. See Sarah E. Igo, The Averaged American 103-49 (2007).

${ }^{156}$ See Bassok, supra note 131, at 158-59.

${ }^{157}$ See Bassok, supra note 131, at 158-60.

${ }^{158}$ Owen M. Fiss, Two Models of Adjudication, in How Does the Constitution Secure Rights? (Robert A. Goldwin \& William A. Schambra eds., 1985) 36, 43-44.

${ }^{159}$ I describe this shift in a more detailed manner in Bassok, supra note 136.

${ }^{160}$ See also SCHMITT, supra note 44, at 30 (explaining that today, "the dominant concept of legitimacy is in fact democratic").

${ }^{161}$ See CALDWELL, supra note 71 , at 100.

${ }^{162}$ SCHMITT, supra note 44, at 48. See also MCCORMICK, supra note 14 , at 225.
} 
opinion even though their legitimacy was transformed from monarchical to democratic. Their public support could be maintained even when they acted against public wishes. For example, the public may still believe in a monarchy's mythical aura. ${ }^{163}$ Similarly, Supreme Court justices may follow originalism because it "sells" in terms of recruiting public support even when their concrete rulings counter public opinion. ${ }^{164}$ However, understanding the Court's legitimacy in sociological rather than normative terms alters the criterion by which the Court's decisions are assessed. Rather than examining Court's actions according to their normative justification, the Court's actions are assessed in terms of ensuring the Court's public support.

The shift in understanding judicial legitimacy fits Schmitt's historical narrative of the way conceptual shifts ensue. Nonetheless, looking through Schmittian eyes at the end-result of this conceptual shift produces a mixed reaction. On the one hand, this shift allows courts to overcome one of the main flaws Schmitt found in their ability to serve as guardians of the constitution. On the other hand, the idea that the support of the people is determined by a technological tool, which is based on a numerical metric, is contrary to Schmitt's approach towards translating the people's voice into numeric data. Let me elaborate on these two points.

Schmitt viewed with disdain attempts to imitate natural science by switching abstract notions such as "virtue" to measurable metrics such as "economic value." For him, measuring legitimacy would be part of the same desperate attempt to turn ethics into science. ${ }^{165}$ Schmitt did not view "secret elections" as the "absolute and conclusive" method for determining the will of the people. ${ }^{166}$ Rather, he saw the method of secret ballots as transforming the citizen from a political being into an unaccountable, private individual. ${ }^{167}$ "The people elect and vote no longer as the people," wrote Schmitt, "[r]ather, they organize a procedure for an individual vote with the addition of individual votes ...." $168 \mathrm{He}$ added that " $[\mathrm{t}]$ he people exist only in the sphere of publicity. The unanimous opinion of one hundred million private persons is neither the will of the people nor public opinion." ${ }^{69}$ On the face of it, Schmitt's disdain of "a mathematical-statistical majority," 170 of aggregated individual wills that replaces the will of the authentic people, contradicts the current American understanding of judicial legitimacy as it is based on opinion poll results. ${ }^{171}$ Yet at the same time that Schmitt presented technology as the final stage in the negative process of political neutralization, he acknowledged the role of technology in defining the political conditions of modernity, including in establishing legitimacy. ${ }^{172}$

\footnotetext{
${ }^{163} C f$. Edward L. Rubin, Beyond Camelot: Rethinking Politics and Law for the Modern State 76 (2005) (explaining that there was a shift in understanding the source of the king's power from a source that is sacred to society's collective will and yet, " $[\mathrm{t}]$ he overall conception remained sacerdotal ... because the collective will was seen as a mystical unity that linked society to the supernatural order").

${ }^{164}$ See, e.g., Jamal Greene, Selling Originalism, 97 GEO. L.J. 661, 695 (2009) (reporting on polls showing that a large segment of the public believes that the Court should adhere to the originalist method of interpretation).

${ }^{165}$ See Carl Schmitt, The Tyranny of Values 9-13 (Simona Draghici ed., Simona Draghici trans., 2001). See also Juah-Pekka Rentto, Carl Schmitt and the Tyranny of Values, in The Contemporary RelevanCE OF CARL SCHMitT: Law, Politics, Theology 64, 69-70 (Matilda Arvidsson, Leila Brännström \& Panu Minkkinen eds., 2016).

${ }^{166}$ SCHMITT, supra note 26 , at 131.

${ }^{167}$ See SchmitT, supra note 26, at 273; SchmitT, supra note 44, at 16-17. See also Ulrich K. Preuss, Carl Schmitt and the Weimar Constitution, in THE OXFord HANDBOOK OF CARL SCHMITT, supra note 40, at 471, 480-81; DyzenHAUs, supra note 21 , at $63-64$

${ }^{168}$ KeLSEN \& SCHMITT, supra note 2, at 273.

${ }^{169}$ SCHMiTT, supra note 44 , at 16.

${ }^{170}$ SCHMITT, supra note 51, at 28. See also id. at 30, 41; MCCORMICK, supra note 14, at 241.

${ }^{171}$ See CARl Schmitt, Roman CATHOlicism and Political Form 25-27 (G.L. Ulmen trans., 1996); SchmiTT, supra note 25, at 305-06 ("A tabulation of what private people think privately produces neither genuine public opinion nor a genuine political decision.”).

${ }^{172}$ Chris Thornhill, Political Theory in Modern Germany - An Introduction 77-78 (2000). See also Schmitt, supra note 7 , at $92-95$.
} 
Although opinion polls were only invented in the US in the 1930s, surprisingly, Schmitt predicted this technological innovation already in 1928 and confronted it head-on. In Constitutional Theory, he wrote that it is "fully conceivable that one day through ingenious discoveries, every single person, without leaving his apartment, could continuously express his opinions on political questions through an apparatus and that all these opinions would automatically be registered by a central office, where one would only need to read them off." 173 For Schmitt, such a development would not be a sign for "an especially intensive democracy," 174 but another demonstration of the infiltration of the technological thinking of mass replication of material objects into political representation. ${ }^{175}$ The people in a world of public opinion polls would be "fully privatized," and there would not be true public opinion, "only a sum of private opinions." "176 Schmitt wanted "the act itself" by the people, rather than an observation of the sum of majority voices as measured and mediated by technology. ${ }^{177} \mathrm{He}$ believed in a notion of "the people" that is "out there," beyond all attempts to reproduce it by technological means. ${ }^{178}$

Schmitt acknowledged that the expression of the people's will through "acclamation" in public displays — such as street demonstrations - has changed in modern states. Currently, the people's will "expresses itself as 'public opinion." 179 In other words, in times of modern normal politics (rather than during a founding moment), "[p]ublic opinion is the modern type of acclamation." 180 The only tool for acclamation remaining, according to Schmitt, is plebiscites, which he characterized as a "decision through one will." 181 In plebiscites, "the people itself cannot discuss .... It can only acclaim, vote, and say yes or no to a question presented to it" from above. ${ }^{182}$ For Schmitt, plebiscitary democracy was an answer to the invasion of constitutional law by the "functionalism of arithmetical-statistical methods." ${ }^{183}$ In a reality of mass democracy with complex bureaucratic governance, plural voices, and conflicting interests, Schmitt thought that "plebiscitary legitimacy is ... the single last remaining accepted system of justification." 184

For this reason, Schmitt believed that the election of the president through plebiscite provides a potent source of legitimacy. He viewed this type of election favorably due to its directness and immediateness against the pluralistic-quantitative majoritarianism of parliament. ${ }^{185} \mathrm{He}$ believed that "the representative must fall silent when the represented themselves talk." 186 Schmitt understood

\footnotetext{
${ }^{173}$ SCHMITT, supra note 25 , at 274.

${ }^{174}$ SCHMITT, supra note 25 , at 274.

${ }^{175}$ SCHMITT, supra note 171 , at 13 . See also MCCORMICK, supra note 14 , at 4, 158, 168-69, 186.

${ }^{176}$ SСнмiтT, supra note 51, at 274-75 ("No public opinion can arise by way of secret individual ballot and through the adding up of the opinions of isolated private people.").

${ }^{177}$ SCHMitT, supra note 25, at 131. See also DyzENHAus, supra note 21, at 52 ("It is an error and an undemocratic one at that, to think that recognition of the will of the people comes about through the results of the system of individual secret ballots. That will is recognized in the deed, and not through observation of a normatively regulated transaction.").

${ }^{178}$ See Horst Dreier, The Essence of Democracy - Hans Kelsen and Carl Schmitt Juxtaposed, in HANS KELSEN AND CARL SCHMitT: A JuXTAPOSITION, supra note 78, 71, at 75-76; JAN-Werner Muller, What is Populism? 27 (2016) (“Such a notion of 'the people' beyond all political forms was influentially theorized by the right-wing legal theorist Carl Schmitt during the interwar period.").

${ }^{179}$ SCHMitT, supra note 25 , at 131, 246-47, 302-03. See also DyzenHAus, supra note 21 , at 57; KALYvAs, supra note 61 , at $124-25$.

${ }^{180}$ SCHMITT, supra note 25 , at 275 .

${ }^{181}$ SCHMITT, supra note 51 , at 89.

${ }^{182}$ SCHMITT, supra note 25 , at 338.

${ }^{183}$ SCHMITT, supra note 51, at 45. See also SCHMITT, supra note 44, at 16-17, 22; MCCoRMICK, supra note 14, at 175, 230. Cf. SCHUPMANN, supra note 7, at 62-64 (arguing that while Schmitt supported plebiscitary democracy as a more legitimate expression of the will of the people until 1928 and adding that in 1928 the situation changed and Schmitt viewed it "to be both politically impotent and highly manipulable.").

${ }^{184}$ SCHMITT, supra note 51 , at 90 .

${ }^{185}$ KELSEN \& SCHMITT, supra note 2, at 141. See also MCCORMICK, supra note 14, at 232, 243 (describing Schmitt's position toward the president and parliament's sources of legitimacy).

${ }^{186}$ SCHMITT, supra note 51 , at 61 .
} 
well that plebiscites are a tool designed to reflect a momentary snapshot of public opinion. ${ }^{187}$ Nonetheless, he viewed parliamentary representation as diminishing the role of the people by narrowing their voice as the "primary organ," and replacing this authentic voice with its mere expression by the people's representatives in a "secondary organ." 188

Schmitt wrote that while the dominance of the democratic ideal is uncontested, the debate is over "the means of identification" of the will of the people. ${ }^{189}$ For this reason, it is not surprising to find inconsistencies in his position regarding the measurement tool. Yet, in many ways, the technology, which is aimed to capture the unorganized voice of the people, evolved from plebiscites in Schmitt's era to public opinion polls in ours. Schmitt saw plebiscites as breaking parliament's "monopoly" on legitimacy emanating from public support, allowing the president to rely on such support. ${ }^{190}$ In a similar fashion, public opinion polls broke the elected institutions' monopoly on the claim to legitimacy based on public support. ${ }^{191}$ Opinion polls provided the Court, for the first time in history, with the ability to rely on what Schmitt termed "confidence from below." 192 While Schmitt emphasized that "the oft-cited 'daily plebiscite' is in reality hardly possible to organize," 193 opinion polling created a technology that has enabled this vision.

The section titled "Democracy and the Judiciary" in Schmitt's book Constitutional Theory further supports the argument that Schmitt would have viewed the invention of public opinion polls as an answer to one major deficiency he found in the judiciary's ability to serve as the guardian of the constitution. In this section, Schmitt discussed the idea that "only the judge that bears the confidence of the people can adjudicate legal claims." ${ }^{194} \mathrm{He}$ viewed the technology for implementing this idea as based on the "recall" of judges by inhabitants of a certain district or on the election of judges in individual districts. ${ }^{195}$ Schmitt acknowledged that, at the time he was writing, it was impossible to fulfill this "democratic requirement from the standpoint of a national democracy." 196 With the invention of public opinion polls that can measure public support for courts on a national scale, this technological problem has been solved. National high courts' current ability to possess evidence of public support based on opinion polls seems to fit Schmitt's view in Constitutional Theory on how courts can hold democratic legitimacy. In this manner, one of Schmitt's major objections to courts as guardians of the constitution is solved.

Yet, we must not forget that Schmitt's problem with the judiciary serving as the guardian of the constitution stemmed not only from the judiciary's source of legitimacy, but also from its inability to decide political questions. In the same section on "Democracy and the Judiciary," Schmitt wrote that "[p]olitical decision is a matter for the legislature and for the political leadership." ${ }^{97}$ The

\footnotetext{
${ }^{187}$ SCHMITT, supra note 51, at 89-90. See also SCHEUERMAN, supra note 7, at 101-02.

${ }^{188}$ SCHMITT, supra note 171, at 26; SCHMITT, supra note 44, at 34. See also KALYVAs, supra note 61, at 168-69.

${ }^{189} \mathrm{Cf}$. SCHMITT, supra note 44 , at 29 ("[A]n identity with the will of the people has become so common a premise that it has ceased to be politically interesting, and that the conflict only concerns the means of identification.").

${ }^{190}$ See SCHMITT, supra note 2, at 149 ("[T] he president of the Reich is elected by the German people as a whole, so that he, as well, is a representative of the people, with the result that the monopoly of the representation of the people that, in the norms and concepts of monarchic constitutional law, is presupposed to inhere in parliament is cancelled."). See also MCCORMICK, supra note 14, at 230 ("Schmitt urges the identification of the popular will with the office of the executive and against the institution of the legislature ....").

${ }^{191}$ See Bassok, supra note 131, at 156.

${ }^{192}$ SCHMITT, supra note 51, at 90.

${ }^{193}$ SCHMITT, supra note 51 , at 89.

${ }^{194}$ SCHMITT, supra note 25 , at 300.

${ }^{195}$ SCHMITT, supra note 25 , at 301.

${ }^{196}$ SCHMITT, supra note 25 , at 301.

${ }^{197}$ SCHMITT, supra note 25 , at 301.
} 
judiciary cannot speak as the authentic delegate of the unified people's will on the nation's existential political decision. ${ }^{198}$ The features that constitute it as an expert make the judiciary unable to decide on existential-political issues. ${ }^{199}$

\section{The Rise of the Israeli Schmitelsen Court}

The change in the way Americans currently view the Supreme Court's source of legitimacy is manifested in their reading of Alexander Hamilton's famous dictum in The Federalist No. 78. As explained above, Hamilton based the Court's legitimacy "merely" on its judicial expertise — "judgment" — not on public support for the Court. ${ }^{200}$ Yet, over the years, this dictum has been paraphrased in judgments of the Court and scholarly writing. ${ }^{201}$ One example of this paraphrasing comes from Justice Felix Frankfurter's dissenting opinion in Baker v. Carr. In his opinion, Frankfurter wrote that "[t]he Court's authority—-possessed of neither the purse nor the sword—ultimately rests on sustained public confidence in its moral sanction." 202 Frankfurter's dictum is now commonly quoted in support of the contention that the Court's legitimacy stems from its public support. ${ }^{203}$

In 1986, Judge Aharon Barak quoted Justice Frankfurter's dictum for the first time in one of his judgments and imported into Israeli jurisprudence the idea that the judiciary's source of legitimacy is public confidence. ${ }^{204}$ Although Frankfurter and Barak share central biographical elements and similar career paths, ${ }^{205}$ Barak expressed his dislike for Frankfurter's persona. ${ }^{206}$ And yet, Barak imported from Frankfurter an idea that would have a central role in his jurisprudence. ${ }^{207}$ Moreover, through Barak's influence, the Israeli Supreme Court (hereinafter: ISC) adopted the idea in many of its judgments that its source of legitimacy lies in "public confidence for the Court." 208 In 2003, former Supreme Court Judge Haim Cohen noted that "[i]f there is one opinion which all Supreme Court judges seem to agree on, it is the need for public confidence in the Supreme Court." 209 This agreement between judges arose during a period in which public opinion polls showed strong support for the ISC. ${ }^{210}$

\footnotetext{
${ }^{198}$ SCHMITT, supra note 25, at 299 (“The judge is bound to the statute. His activity is essentially normatively determined. He is not an independent representative of the political unity as such."). See also Preuss, supra note 167, at 478; SCHUPMANN, supra note 7, at 167 (noting, following Hofmann, that the court cannot serve as a guardian because "the judiciary lacked democratic legitimation.").

${ }^{199}$ See SEITZER, supra note 38 , at 55-56.

${ }^{200}$ See Keith E. Whittington, Constitutional Interpretation 54 (1999) (explaining that, according to Alexander Hamilton, "the court's only claim to authority is the force of its reason and the clear accuracy of its decision").

${ }^{201}$ See Bassok, supra note 136, at 575-78.

${ }^{202}$ Baker v. Carr, 369 U.S. 186, 267 (1962).

${ }^{203}$ See, e.g., James W. Stoutenborough \& Donald P. Haider-Markel, Public Confidence in the U.S. Supreme: A New Look at the Impact of Court Decisions, 45 Soc. SCI. J. 28, 29 (2008) (referring to The Federalist No. 78 and to Frankfurter's quote from Baker v. Carr and noting that "[1] egitimacy is tied, to a great extent, to the public's confidence, or specific support, in the Court as an institution .... and without a reservoir of goodwill the Court will struggle to maintain its legitimacy”).

${ }^{204}$ See HCJ 732/84 Tzaban v. Minister of Religious Affairs 40(4) PD 141, 148-49 (1986) (Isr.).

${ }^{205}$ Both were Jews who migrated from Europe at a young age; both were young law professors who had strong influence on the academia throughout their career; and both had close relationship with the head of the executive at a certain stage of their career-Frankfurter with President Franklin D. Roosevelt, and Barak with Prime Minister Menachem Begin.

${ }^{206}$ Noami Levitsky, The Supremes: Inside the Supreme Court 150 (2006) ("Barak often quotes Frankfurter, but in a private conversation he confessed that he does not like him, 'he was not a proud Jew,' said Barak.").

${ }^{207}$ See Aharon Barak, Foreword: A Judge on Judging: The Role of a Supreme Court in a Democracy, 116 HARV. L. REV. 16, 5960 (2002) (referring to Frankfurter's dictum from Baker v. Carr and noting "[i]ndeed, the judge has neither sword nor purse. All he has is the public's confidence in him"). Interestingly, Frankfurter's drafts in Baker demonstrate that his position was different than the one Barak and many American scholars attribute to him. See Bassok, supra note 136, at 579-81.

${ }^{208}$ See, e.g., HCJ 4481/91 Bargil v. The Government of Israel 47(4) PD 210, 220 (1993) (Isr.); HCJ 5364/94 Velner v. Chairman of Israeli Labor Party [1995] 49(1) PD 758, 785-86, 826 (1995) (Isr.) [hereinafter HCJ 5364/94].

${ }^{209}$ Haim Cohen, Thought of Disbelief in Public Confidence, in Sefer Shamgar 365, 365, 370-71 (Barak et al. eds., 2003).

${ }^{210}$ See Gad Barzilai, Ephraim Yuchtman-Ya'ar \& Zeev Segal, The Israeli Supreme Court and the Israeli Public (1994) (presenting the results of an extensive opinion poll conducted in 1991 showing a very high level of support for the ISC);
} 
In 1986 when Barak first put forward the idea that the ISC's legitimacy is based on public support, the ISC was hardly a Schmitelsen court. In the following paragraphs, I will show that the importation of the idea that the ISC requires public confidence was part of Barak's endeavor to transform the ISC into a Schmitelsen Court. But first, in order to understand this transformation, a brief background on Israeli constitutional history is required.

It is undisputed that until 1992, Israel lacked a formal constitution. ${ }^{211}$ Although Israel's 1948 Declaration of Independence included a commitment to enact a constitution, this commitment was never fulfilled. The first elected assembly - the first Knesset-held both the role of a constituent assembly and the role of an ordinary legislator. In 1950, after a spirited, year-long debate on the issue of establishing a constitution for Israel, the Knesset reached a compromise known as the Harari Resolution. ${ }^{212}$ According to this resolution, the Israeli Constitution would be composed of separate, Basic Laws. These Basic Laws would be enacted gradually by the Knesset and together they would constitute the state's constitution. ${ }^{213}$ In accordance with the Harari Resolution, until 1992 the Knesset enacted nine Basic Laws, all focused on the institutional or structural aspects of Israel's regime. ${ }^{214}$

As for judicial review over legislation, since the 1968 Bergman ruling, ${ }^{215}$ courts have held the power to review and annul only laws that violated entrenched provisions in the Basic Laws. Apart from this narrow and limited power, courts did not possess any power of judicial review over legislation. Non-entrenched provisions in the Basic Laws were considered for all practical matters the same as provisions in regular laws. ${ }^{216}$

In 1992, the Knesset enacted Basic Law: Freedom of Occupation and Basic Law: Human Dignity and Liberty, which established a partial bill of rights. In 1995, the Supreme Court, led by its new President Aharon Barak, decided in Bank HaMizrachi that the Court has the power to invalidate laws inconsistent with the 1992 Basic Laws without any link to the question of entrenchment. $^{217}$ The Court also began establishing the understanding that the 1992 legislation created normative gradation, so that all of the Basic Laws should be seen as higher law, that is, as Israel's constitution. ${ }^{218}$ This last move of proclaiming that Israel has a formal constitution that consists of its eleven Basic Laws led the former president of the ISC, Moshe Landau, to claim that under the leadership of Barak, the court was "granting Israel a constitution through court decisions." 219 In the years since the Bank HaMizrachi judgment, these two ingredients-judicial review based on the 1992 Basic Law and viewing the eleven Basic Laws as Israel's Constitutionwere consistently promoted by the ISC and are known as Israel's "constitutional revolution."

In Bank HaMizrachi, Barak argued that the "Weimar lessons" teach us of the need for judicial review. He wrote that "[o]ne of the lessons of the Second World War was that constitutional supremacy and judicial review of constitutionality are potent weapons against the enemies of

\footnotetext{
Or Bassok, Television Coverage of the Israeli Supreme Court between 1968 and 1992: The Persistence of the Mythical Image, 42 IsR. L. REV. 306, 307-08 (2009) (surveying various polls from the 1980s and 1990s).

${ }^{211}$ See Melville B. Nimmer, The Uses of Judicial Review in Israel's Quest for a Constitution, 70 CoLUM. L. REV. 1217,1219 (1970).

${ }^{212}$ See, e.g., Gideon Sapir, Constitutional Revolutions: Israel as a Case-study, 5 INT'L J. LAW CONTEXT 355, 358-59 (2009).

${ }^{213}$ See, e.g., Yoseph M. Edrey, The Israeli Constitutional Revolution/Evolution, Models of Constitutions, and a Lesson from Mistakes and Achievements, 53 AM. J. COMP. L. 77, 81-82 (2005).

${ }^{214}$ Suzie Navot, The Constitutional LaW of Israel 36-37 (2007).

${ }^{215}$ HCJ 98/69 Bergman v. Minister of Finance 23(1) P.D. 693 (1963) (Isr.).

${ }^{216}$ Violations of entrenched provisions in the Basic Laws were permissible only if the violating law was enacted with the special majority required by the entrenched provision. For a detailed description of the Bergman judgment, see Robert A. Burt, Inventing Judicial Review: Israel and America, 10 CARdozo L. Rev. 2013, 2043-47 (1989); Ruth Gavison, The Israeli Constitutional Process: Legislative Ambivalence and Judicial Resolute Drive, 11 REv. Const. STUD. 345, 368 (2006).

${ }^{217}$ CA 6821/93 Bank HaMizrachi United Ltd. v. Migdal Communal Village 49(4) PD 221 (1995) (Isr.) [hereinafter CA 6821/93]

${ }^{218}$ See Gavison, supra note 216 , at 371-72.

${ }^{219}$ Moshe Landau, Granting Israel a Constitution Through Court Decisions, 3 MishPAT U-Mimshal 697, 705-706 (1996) (emphasis added).
} 
democracy." ${ }^{220}$ He repeated this argument on many occasions following the Bank HaMizrachi judgment. ${ }^{221} \mathrm{He}$ also frequently connected the lessons of Weimar and those of the Holocaust. ${ }^{222}$ Barak's historical account of Weimar is dubious at best, ${ }^{223}$ but it is not surprising that the Weimar lessons play such an important role in his thought in view of his experience as a Holocaust survivor.

A few years after Bank HaMizrachi, Barak began inserting the idea of the ISC as the guardian of the constitution (in Hebrew: Shomer H'Hocka) into Israeli constitutional discourse. He explained that " $[\mathrm{t}]$ he role of a judge is to protect the constitution and its values, to guard them and promote them ... 'the judges are the guardians of the constitution." 224 He added that "[ $t]$ he chief contribution of judicial review is in guarding the constitution and its values. This is also the main role of the judge. From here derives the vital importance of this tool for the fulfillment of the judicial role." 225

While Barak attributed the role of the guardian of the constitution to a court-as the Kelsenian model suggests-Barak's guardian functions more as a Schmittian guardian. This is perhaps most evident once we analyze passages in Barak's writings that are reminiscent to Kelsen's famous sinking ship passage.

In 1929, Kelsen discussed the question: What should a democrat do when the majority wishes to destroy democracy? According to Kelsen, posing this question already means answering it. A democracy that tries to assert itself against the will of the majority has ceased to be a democracy. The rule of the people cannot continue to exist against the people. And how should the democrat behave? "One must remain true to his colors, even when the ship is sinking, and can take with him into the depths only the hope that the ideal of freedom is indestructible and that the deeper it has sunk, the more passionately will it revive."226

Kelsen was well aware that a constitutional court is not "an absolutely effective guarantee under all conceivable circumstances." ${ }^{27}$ He wrote that "[a] constitutional court is indeed a wholly useless instrument to prevent the turn towards the total state." 228 In view of the limits of the constitutional court's abilities, Kelsen added that the president is one of the guardians of the constitution: It is his role, too, to ensure the constitution is not violated. ${ }^{229}$

Barak presented a different model of what a democrat should do when the ship is sinking. In Velner (1994), the ISC addressed the legality of a provision in a coalition agreement between two

\footnotetext{
${ }^{220} \mathrm{CA} 6821 / 93$, at 415 .

${ }^{221}$ See, e.g., Aharon Barak, The Role of a Supreme Court in a Democracy, and the Fight Against Terrorism, U. MIAMI L. REV. 125, 125-26 (2003) ("a lesson of the Holocaust and of the Second World War is the need to enact democratic constitutions and ensure that they are put into effect by supreme court judges whose main task is to protect democracy.").

${ }^{222}$ See, e.g., Barak, supra note 207, at 37, 38.

${ }^{223}$ See Or Bassok, A Decade to the "Constitutional Revolution": Israel's Constitutional Process from a Historical-Comparative Perspective, 6 Mishpat Umimshal 451, 461-63 (2003) (discussing the existence of judicial review in the Weimar Republic and its inability to stop the Republic's demise); Michael Mandel, A Brief History of the New Constitutionalism, Or "How We Changed Everything So That Everything Would Remain The Same", 32 IsR. L. R. 250, 250-69 (1998) (noting that Barak's "Weimar's lesson" "simply bears no relation to historical reality").

${ }^{224}$ Aharon Barak, The Judge In a Democracy 320-21 (2004) [in Hebrew]. An English translation to Barak's book The Judge in A Democracy was published in 2006. Barak supports the sentence quoted in the text above with reference to two sources. First, Barak refers to Canadian Justice Dickson's judgment in Hunter v. Southam, [1984] 2 S.C.R. 145, 155 (Can.) ("The judiciary is the guardian of the constitution"). Second, Barak refers to a Hebrew translation of a lecture by the then German President of the German Constitutional Court, Justice Jutta Limbach, The Role of the Federal Constitutional Court as the Guardian of the Constitution, 28 Mishpatim 5 (1997). For similar statements in English, see Barak, supra note 207, at 36.

${ }^{225}$ BARAK, supra note 224 , at 320-321.

${ }^{226}$ Clemens Jabloner, Hans Kelsen - Introduction, in WEIMAR - A JURISPRUdENCE OF CRISIs 74 (Arthur J. Jacobson \& Bernhard Schlink eds., 2000).

${ }^{227}$ KeLSEN \& SCHMITT, supra note 2, at 181.

${ }^{228}$ KELSEN \& SCHMITT, supra note 2, at 203.

${ }^{229}$ See KELSEN \& SCHMITT, supra note 2, at 212-13 ("That the president is one guardian of the constitution ... is something no one will deny.").
} 
parties. The provision established an automatic procedure for altering, by means of legislation, any holding by the ISC that would violate the prevailing status quo in religious matters. Although all the judges strongly criticized the agreement, the majority decided that the agreement should not be voided. Subsequently, the ISC dismissed the petition. Barak, in dissent, would have annulled the provision since its

$[\mathrm{C}]$ ontent contradicts the constitutional public policy ('ordre public'). This contradiction is dual: first, it undermines the position of the judiciary. It may undermine the independence of the judge and the public confidence in judges. Second, it undermines the principle of separation of powers .... This is an agreement that 'by-passes democracy'. This agreement is void $a b$ initio. It cannot be introduced in a state that establishes 'in a Basic Law the values of the State of Israel as a Jewish and democratic state' (section 1A. Basic Law: Human Dignity and Liberty; section 2 Basic Law: Freedom of Occupation). ${ }^{230}$

In his judgment Barak discussed the question of non-justiciability of a political agreement. In earlier cases, Barak had already ruled that those agreements were justiciable, ${ }^{231}$ but in Velner he stressed that even if those agreements are non-justiciable,

[T] he part that undermines constitutional public policy turns justiciable. Indeed, the declaration of nullity of the agreement stems from the basic notion of a society that wants to take precautionary measures and wants to defend itself against those who try to infringe its basic values. This is an expression of the defensive democracy (In the words of Judge Sussman in Yardor ... ) that defends itself from the plausible and actual —in our case very plausible and actual-possibility of infringing its most basic values ... we should not recoil. We are the guardians of the constitutional wall. We must block this breach. Otherwise, the whole wall will be in danger. ${ }^{232}$

Faced with the possibility of breaches of the values at the core of the constitution, Barak was not passive. He would not merely watch the ship while it sinks:

We must never relax the protection of the rule of law. All of us-all branches of government, all parties and factions, all institutions-must guard our young democracy. This protective role is conferred on the judiciary as a whole, and on the Supreme Court in particular. Once again, it was casted on us, the judges of this generation, to stand and guard our basic values, to protect them against those who rise against them. ${ }^{233}$

Thus, in a dissenting opinion, Barak made "the additional move," beyond the majority judgment, and declared that the provision is void. ${ }^{234}$

Barak's guardian did not follow the footsteps of the Kelsenian guardian. Like Schmitt, Barak was willing to break the constraints of legality in order to protect the polity's political decision. Barak will not watch the ship sink while remaining "true to his colors." This is most evident in his approach to the idea of supra-constitutional values that allows laws and even constitutional amendments to be struck down. According to Barak, the guardian is entrusted with defending the unwritten fundamental values that stand above the legislation and even above the constitution.

\footnotetext{
${ }^{230} \mathrm{HCJ} 5364 / 94$, at 784. In his Harvard article, Barak wrote that in Velner, "the coalition agreement was void because it undermined the fabric of democratic life, which is contrary to public policy." Barak, supra note 207, at 135-36.

${ }^{231}$ HCJ 1635/90 Jerjevsky v. Prime Minister 45(1) PD 749 (1993) (Isr.); HCJ 1601/90 Shalit v. Peres 44(3) PD 353 (1990) (Isr.).

${ }^{232} \mathrm{HCJ} 5364 / 94$, at 793-94, 799.

${ }^{233} \mathrm{HCJ} 5364 / 94$, at 808 . See also Barak, supra note 207, at 37-38.

${ }^{234} \mathrm{HCJ} 5364 / 94$, at 804 .
} 
In times of need, the guardian may act in the name of these values to annul laws and even constitutional amendments. ${ }^{235}$ This was not merely an idea that Barak raised in his scholarly writings. ${ }^{236}$ As will be described below, in central judgments - both before the constitutional revolution and after it-Barak raised the option of striking down laws and even constitutional amendments in the name of supra-constitutional values. Such an authority is part of the Schmittian model of the guardian. Kelsen rejected Schmitt's approach of limiting the amending power by using values that are unwritten in the constitution. ${ }^{237}$

Before the constitutional revolution, in his dissenting opinion in Laor Movement v. Speaker of the Knesset (1990), ${ }^{238}$ Barak discussed the question of whether a law regulating the financing of political parties could be annulled because it infringed the basic value of equality that was not specified in the Basic Laws. Barak accepted that this law did not violate the terms of an entrenched provision in a Basic Law as was required in that period for striking down legislation. For this reason, his discussion dealt with constitutional values that stand above the constitution. Barak ruled that the court could, "on doctrinal-principle level," strike down a law that contradicts the basic and fundamental principles of the system, even though those principles are not anchored in a formal constitution or an entrenched Basic Law, and even though the court had not received any legislative authorization for such an act. However, Barak conceded that

[I]n view of the social-legal understanding in Israel and in view of the consistent jurisprudence of this court over the years, it is improper for us to diverge from our position that reflects our legal-political tradition, it is improper to adopt a new position, that acknowledges the Court's power to declare a law void when it does not contradict an entrenched provision in a Basic Law and does contradict the basic values of the system. If we do so, we will be perceived by the public as if we diverged from the social consensus as for the role and the power of a judge in Israeli society. The perception of the judicial role by Israeli society is not in line with such a far-reaching ruling. ${ }^{239}$

In Laor, Barak accepted the idea of basic values that serve as unwritten limitations on legislation. Nevertheless, one central reason for his refusal to endow the ISC with the power of judicial review, that relies on unwritten limitations, was the lack of "social consensus" behind the idea that the ISC would hold such power. Barak understood well the lesson Schmitt offered: In order to fulfill its extraordinary functions, the guardian must enjoy public support. The connection in Barak's mind between his dissenting opinion in Laor and the Weimar lessons is perhaps most evident in the following paragraph from Barak's Bank HaMizrachi opinion:

Indeed, in a number of common law nations the recognition is slowly developing that certain fundamental values cannot be impaired by the legislator, even without a written constitution. The bitter experience of Nazi Germany, inter alia, has contributed to the understanding of this issue (see my judgment in Laor .... .) $)^{440}$

\footnotetext{
${ }^{235}$ Aharon Barak, The Constitutional Revolution - 12 Anniversary, 1 L. \& BUs. 3, 18 (2004) ("I accept that situations may demand judicial review though a constitution is absent or even in respect to the articles of the constitution.").

${ }^{236}$ Aharon Barak, Unconstitutional Constitutional Amendments, 44 IsR. L. REV. 321 (2011).

${ }^{237}$ Klein, supra note 84 , at 65 .

${ }^{238}$ HCJ 142/89 Laor Movement v. Speaker of the Knesset 44 (3) PD 529 (1990) (Isr.).

${ }^{239}$ Id. at 554 .

${ }^{240} \mathrm{CA} 6821 / 93$, at 398-99. I corrected a minor mistake in the official translation- “accepted legal systems" was corrected to "common law". Before Bank HaMizrachi, Barak wrote in Velner that the question of the ISC's power to annul a law or Basic Law that infringes basic values is a hard question that requires further study. He concluded by writing: "[1]et us hope we shall never have to decide on this question. In any case such a decision is not needed in the petitions before us." HCJ 5364/94, at 798.
} 
In 2006, after the constitutional revolution was already well-established in the ISC's adjudication, Barak wrote in an obiter in one of his last major constitutional judgments that the ISC holds the authority to strike down unconstitutional constitutional amendments. ${ }^{241}$ Not only did Barak follow Schmitt in endowing the guardian with this authority, but he also identified Israel's basic political decision in the Basic Laws without an explicit eternity clause, as did Schmitt with the Weimar Constitution. ${ }^{242}$ Barak spoke of "the character of Israel as a Jewish and democratic state" as the state's political decision that cannot be negated even by a constitutional amendment. ${ }^{243}$ While the formula of "Jewish and democratic" state is anchored in the purpose clause of both Basic Law: Freedom of Occupation and Basic Law: Human Dignity and Liberty, Barak elevated it to the status of Israel's unalterable political decision. Yet, it is important to stress that the issue of public support for the ISC played a key role in Barak's view of the doctrine of unwritten limitations on the constitutional amendment power. After all, as his dissent in Laor shows, even before the 1992 Basic Laws, Barak spoke of fundamental values that stand above the legal system and allow the ISC to review legislation. The change from the time of his dissenting opinion in Laor to his support of the adoption of the unconstitutional constitutional amendment doctrine in the 2000s has been not only the enactment of the 1992 Basic Laws, but also the ISC's ability to rely on public support as its source of legitimacy. ${ }^{244}$

\section{E. A European Schmitelsen Court?}

Drafted in view of the horrors of the Second World War, the European Convention on Human Rights and Fundamental Freedoms (ECHR) is an international treaty that was opened for signature in 1950 and entered into force in 1953. From the outset, the founders of the ECHR understood that legal expertise is not a sufficient source of legitimacy for a proper guardian of the Convention. In this context, the Weimar lessons weighed heavily on their mind.

The institutional setting originally devised in the ECHR positioned the European Commission of Human Rights as the body responsible for examining complaints from contracting states. Envisaged as a quasi-judicial, quasi-political body, the Commission's report would only express an opinion and thus provide the basis for a determination of the human rights issues by a political body: The Committee of Ministers. ${ }^{245}$ The Commission's recommendations were not legally binding unless adopted by the Committee of Ministers. ${ }^{246}$ Thus, the metric for detecting violations and resolving controversies was not legal, but political. ${ }^{247}$ The Commission could also launch proceedings before the European Court of Human Rights (ECtHR) as long as the states involved had

\footnotetext{
${ }^{241} \mathrm{HCJ}$ 6427/02 Movement for Quality of Government in Israel v. The Knesset 61(1) PD 619, 714-17 (2006) (Isr.) [hereinafter HCJ 6427/02] ("[T]here is a room for the conception that a law or a Basic Law, that will negate the character of Israel as a Jewish of a democratic state, will be unconstitutional ... Our case does not fall to this narrow frame"). In 1996 Barak wrote that "even assuming - without deciding on this matter-that there are basic principles and purposes that an ordinary law cannot undermine, these will be basic principles and purposes that all our constitutional structure, including the Basic Laws themselves, are founded upon, and that the abuse of them is substantive and hard (compare: Yardor; Laor) ....”); HCJ 4676/94 Mitrael Ltd. v. Israeli Knesset 50(5) PD 15, 26 (1996) (Isr.).

${ }^{242}$ On Schmitt's approach, see Vinx, supra note 21 , at 10-11.

${ }^{243} \mathrm{HCJ} 6427 / 02$, at $\$ \$ 72-74$.

${ }^{244} \mathrm{On}$ the impact of public opinion polls that measure support for the ISC on its jurisprudence, see Or Bassok, Two Concepts of Judicial Legitimacy, in JUdGES AS GUARDIANS OF CONSTITUTIONALISM AND HUMAN RigHTS 50, 67-69 (Martin Scheinin, Helle Krunke \& Marina Aksenova eds., 2016).

${ }^{245}$ Ed Bates, The Evolution of the European Convention on Human Rights: From its Inception to the Creation of a Permanent Court of Human Rights 120 (2010).

${ }^{246}$ See Mikael Rask Madsen, The Challenging Authority of the European Court of Human Rights: From Cold War Legal Diplomacy to the Brighton Declaration and Backlash, 79 L. \& ConTEMP. Probs. 141, 146 (2016).

${ }^{247}$ See id. at 146; BATES, supra note 245 , at 92.
} 
recognized its jurisdiction. ${ }^{248}$ The jurisdiction of the ECtHR - that was established by the ECHR and came into being only in 1959-was dependent in that period upon acceptance by state parties to the Convention. These arrangements reflected the mindset of most of the states that had been involved in the Convention's negotiation and opposed the creation of a court outright. ${ }^{249}$

During the period in which the ECHR was drafted, members of the European Movement who viewed a judicial institution as central to the European human rights regime envisioned it as an institution that would have been capable of saving the Weimar Republic at the apex of the 1932 Weimar constitutional crisis. ${ }^{250}$ In 1932, the German elites believed that by giving Chancellor von Papen the authority to take over the governmental machinery of Prussia- the most powerful German state at that time - the Nazis' and the Communists' rise to power could be stopped. In response to the emergency decree which made von Papen commissioner of Prussia, the Prussian government sought an interim injunction from the State High Court (Staatsgerichtshof) ${ }^{251}$ to prevent him from taking office while the legality of the emergency decree was examined. The High Court refused to give the injunction, and its final judgment effectively gave the Federal government the free hand it wanted in Prussia's internal affairs. ${ }^{252}$ Many commentators consider this decision to be the final blow to the Weimar Republic. ${ }^{253}$ According to the fantastic scenario some of the founders of the ECHR had in mind, a judgment of the European court would have condemned the von Papen government's "authoritarian acts," leading to a "public resentment against the Government." 254 As a result, all democratic forces would unite behind a democratic government that would prevent the rise of Adolf Hitler. The court's ruling would serve as the trigger, but the picture was one in which the European public, standing in support of the European court's judgment, saves Europe. ${ }^{255}$

Indeed, the lessons of the Weimar Republic and the Nazi Regime stood at the core of the creation of the ECHR, and the idea of a judicial institution enjoying the support of the people of Europe was prominent among those lessons. Ed Bates elaborated this point and further added "Churchill had no doubt that 'the great body of public opinion' in the free democracies of Europe 'would press for action' so as to ensure the judgment of the European Court would be secured."256 The central mission of the ECHR's judicial body was not understood as necessarily legal, and the manner to ensure compliance in the rare cases the court was to rule was through recruiting public opinion.

In that period, European human rights law was under-developed and was not considered "real law," but more a tool of diplomacy ("legal diplomacy") as part of Western Cold War ideology. ${ }^{257}$ In the early decades of the Convention, there was no community of lawyers holding expertise in the law of the ECHR and no body of doctrinal human rights law. ${ }^{258}$ Human rights were not considered then to be within the exclusive expertise of jurists. ${ }^{259}$ No one could have predicted at the

\footnotetext{
${ }^{248}$ See Armin von Bogdandy \& Ingo Venzke, In Whose Name?: A Public Law Theory of International AdJUDiCATION 64 (2014).

${ }^{249}$ See BATES, supra note 245, at 8-9; Madsen, supra note 246, at 66, 71 ("[A]t the time of negotiating the Convention, there was little political will to set up entirely independent legal institutions.”).

${ }^{250}$ European Movement, European Movement and the Council of Europe 126 (1949).

${ }^{251}$ According to the Weimar Constitution, this court was designed to resolve constitutional disputes between the federal government and the various German states.

${ }^{252}$ The story of the crisis is summarized in DyzenHaus, supra note 21 , at 2-3, 30-37.

${ }^{253}$ See SEITZER, supra note 38 , at xiv.

${ }^{254}$ European MOVEMENT, supra note 250, at 126.

${ }^{255}$ European Movement, supra note 250, at 126.

${ }^{256}$ BATES, supra note 245 , at 7.

${ }^{257}$ See Mikael R. Madsen, Legal Diplomacy_Law, Politics and the Genesis of Postwar European Human Rights, in Human Rights in the Twentieth Century 63, 66, 69, 78-79 (Stefan-Ludwig Hoffmann ed., 2011); Madsen, supra note 246 , at $150-51$

${ }^{258}$ See Madsen, supra note 257 , at $78-79$.

${ }^{259}$ See Madsen, supra note 257, at 73 n. 43.
} 
time that lawyers would eventually lead a juridical reading of the Convention, and that even in times of relative tranquility, the substance and procedures of protection of human rights, as anchored in the Convention, would have effect in national systems. ${ }^{260}$

During the early years, based on a particular reading of the institutional design originally anchored in the ECHR, the Commission led the way by "adopting a diplomatic stand." ${ }^{261}$ It exhibited a preference towards negotiation-based settlements and conflict-resolution decisions driven by diplomatic considerations. ${ }^{262}$ Gradually, the European human rights regime transformed into a dynamic area of law, and the Convention was increasingly viewed as a type of European Bill of Rights, rather than just an instrument to prevent the rise of totalitarianism. ${ }^{263}$ The ECtHR had an active role in this transformation. From the mid-1970s onward, the ECtHR created a substantial body of human rights case law focusing on individual petitions as the center of its work rather than inter-state applications. While progress was still dependent on states' acceptance of ECtHR's jurisdiction and the right to individual petition, the Strasbourg system became increasingly juridical in nature during the 1980s. ${ }^{264}$ With the entrance into force of Protocol 11 in 1998, the right to individual petition became entrenched, and the ECtHR was transformed into a permanent court with compulsory jurisdiction. ${ }^{265}$ The system of protection has become "fully judicial and the court is recognized as a quasi-constitutional" court in the field of human rights. ${ }^{266}$ Since the 1990s, some commentators wish not only to reject the view that the system has characteristics of legal diplomacy, but also to adopt the view that the system is part of constitutional law, rather than merely international law. ${ }^{267}$

Yet, the idea that the institution that decides on violations of the ECHR requires public support and not merely legal expertise has persisted even after the juridification of the European human rights regime. A search of the phrase "public confidence" and other similar phrases in the ECtHR's HUDOC judgments database shows that the ECtHR speaks time after time of the judiciary's need for public confidence to function properly. From 1993 to July 2018, the ECtHR referred to the

\footnotetext{
${ }^{260}$ See Madsen, supra note 257, at 67-68.

${ }^{261}$ See BATES, supra note 245 , at 224, 257-60.

${ }^{262}$ See Henri Rolin, Has the European Court of Human Rights a Future?, 11 HowARD L.J. 442, 443-48 (1965) (discussing the original ECHR's design aimed to allow the Commission to achieve friendly settlements and the extensive use of this option); BATES, supra note 245, at 212-25 (explaining that pre-1965 central cases were not referred to the ECtHR but were resolved through interaction between the Commission and the relevant contacting state thus raising the question "does the European Court of Human Rights have a future?", and showing how diplomatic considerations affected the Commission's behavior during the 1960s); Anthony Lester, The European Court of Human Rights After 50 Years, in THE EUROPEAN COURT OF Human Rights Between Law and Politics 98, 100 (Jonas Christoffersen \& Mikael Rask Madsen eds., 2011) (discussing the use of "diplomatic skills ... to win the confidence of governments" in the early days of the ECHR).

${ }^{263}$ See Madsen, supra note 257, at 80; BATES, supra note 245, at 305-06, 308-09, 365-69, 371, 376, 386.

${ }^{264}$ See BATES, supra note 245, at 275, 401 ("[B]y the mid to late 1970 .... For most of the Conventions States human rights issues were coming under the control of law, not politics."); vON BOGDANDY \& VENZKE, supra note 248, at 68 ("From the 1980s onward ... [t] he centre of the control system shifted increasingly to the Court.").

${ }^{265}$ See Madsen, supra note 246, at 161 (“[T] he supranational protection of human rights in Europe was fully judicialized.”); Laurence R. Helfer \& Anne-Marie Slaughter, Toward a Theory of Effective Supranational Adjudication, 107 YALE L.J. 273,296 (1997).

${ }^{266}$ BAtes, supra note 245, at 25. See also id. at 399-400, 461-62, 466; Nico KiRsCh, Beyond Constitutionalism: The Pluralist Structure of Postnational Law 139-40 (2010) (arguing that during "early years" the European Commission of Human Rights "often assumed a mediatory rather than adjudicatory role" but that this legal diplomacy tactic has declined "as the judicial function became increasingly settled").

${ }^{267}$ See, e.g., Loizidou v. Turkey, App. No. 15318/89, para. 75 (Mar. 23, 1995), http://hudoc.echr.coe.int/eng?i=001-57920 (referring to the Convention "as a constitutional instrument of European public order (ordre public)"); David Kosař, Policing Separation of Powers: A New Role for the European Court of Human Rights?, 8 EuR. Const. L. Rev. 33, 60-61 (2012) (“On numerous occasions it has been claimed the ECtHR is a constitutional court.”); BATES, supra note 245, at 441-43, 467, 479, 497-98.
} 
need for public confidence or public trust in a court or in the judiciary in at least sixty-six judgments. ${ }^{268}$ For example, in Erdoğan and Others v. Turkey (2014), the ECtHR held that "the Court has on many occasions emphasized the special role in society of the judiciary, which, as the guarantor of justice, a fundamental value in a State governed by the rule of law, must enjoy public confidence if it is to be successful in carrying out its duties." ${ }^{269}$ Similar statements were made by the ECtHR in sixty-five other judgments.

Admittedly, almost all the cases in which the ECtHR has referred to public confidence as the source of the judiciary's legitimacy concern national courts and not the ECtHR. ${ }^{270}$ Take for example, Morice v. France (2015). In this case, the ECtHR Grand Chamber notes that the "judiciary in society ... must enjoy public confidence if it is to be successful in carrying out its duties." 271 Yet, the ECtHR speaks in general terms of courts or the judiciary. In other words, it can hardly exclude itself from these general statements on courts' source of legitimacy. As demonstrated already in the 1960s - most notably in the Lawless judgment - the ECtHR has stressed its nature and role as a court since its early days. ${ }^{272}$ Therefore, there is no reason to believe that the ECtHR excludes itself from the category of the "judiciary" or "courts" when it states that they require public confidence.

An argument can be made that "public confidence" should be read as referring to an abstract concept of democratic sovereignty or "the People" rather than to actual sociological public support. Scholars Armin von Bogdandy and Ingo Venzke write that the formula "in the name of the people," used by domestic courts to describe "in whose name" they decide cases invokes the authority of the democratic sovereign. ${ }^{273}$ For example, according to Article 25(4) of the German Law on the Federal Constitutional Court, the judgments of the Constitutional Court are issued "in the name of the people." ${ }^{274}$ There is at least one scholar who views the invocation of this formula by the German Constitutional Court as referring to actual public support for the Court. ${ }^{275}$ However, von Bogdandy and Venzke correctly view this formula as a reflection of an older concept of popular sovereignty that is detached from the actual public support as measured in public opinion polls. ${ }^{276}$ According to this older concept, the democratic subject is a single collective, mostly a nation or a people, rather than the accumulation of individual voices. ${ }^{277}$

\footnotetext{
${ }^{268}$ For my method \& results, see Or Bassok, The European Consensus Doctrine and the ECtHR Quest for Public Confidence, in Building Consensus on European Consensus: Judicial InTerpretation of Human Rights in Europe AND Beyond 236 (Panos Kapotas \& Vassilis Tzevelekos eds., 2019).

${ }^{269}$ Erdoğan and Others v. Turkey, App. Nos. 346/04 and 39779/04, para. 42 (May 27, 2014), http://hudoc.echr.coe.int/eng? $\mathrm{i}=001-144129$.

${ }^{270}$ But see recently in Eskerkhanov and Others v. Russia, App. Nos. 18496/16, 61249/16, and 61253/16, para. 7 (July 25, 2017), http://hudoc.echr.coe.int/eng?i=001-194448, where Judge Pastor Vilanova argued in his dissenting opinion that the that the ECtHR's "authority and prestige also depend on it applying to itself the rules that it lays down for the domestic courts. This is required to preserve the principles of equality, legal certainty and public confidence."

${ }^{271}$ Morice v. France, App. No. 29368/10, para. 128 (Apr. 23, 2015), http://hudoc.echr.coe.int/eng?i=001-154265.

${ }^{272}$ Lawless v. Ireland, App. No. 332/57, paras. 13-16 (Nov. 14, 1960), http://hudoc.echr.coe.int/eng?i=001-57516 (grounding its decision, in part, on the nature of the ECtHR as a court).

${ }^{273}$ Armin von Bogdandy \& Ingo Venzke, In Whose Name? An Investigation of International Courts' Public Authority and Its Democratic Justification, 23 EUR. J. INT'L L. 7, 7-8 (2012).

${ }^{274}$ See Bundesverfassungsgerichtsgesetz, Act on the Federal Constitutional Court (2018), https://www. bundesverfassungsgericht.de/SharedDocs/Downloads/EN/Gesetze/BVerfGG.pdf;jsessionid=017752E8F0215E46B9BD30B8F 2AAAF06.2_cid394?_blob=publicationFile\&v=10. For other examples, see VON BoGDANDY \& VENZKE, supra note 248 , at 20, fn. 94-95.

${ }^{275}$ See Collings, supra note 5, at 185 ("Enormous popular regard for the Court coupled with galloping disenchantment with politicians and political parties helped justify, at least indirectly, the Court's practice of announcing its judgments 'Im Namen des Volkes."').

${ }^{276}$ See VON BOGDANDY \& VENZKE, supra note 248, at 20.

${ }^{277}$ See VON BOGDANDY \& VENZKE, supra note 248, at 140.
} 
While the ECtHR does not use "public confidence" as a fixed formula in the opening lines of its judgments like many domestic courts do, ${ }^{278}$ one may argue that the ECtHR's reference to "public confidence" is substantively similar to an abstract concept of "the people of Europe." Yet the ECtHR has not used the phrase "in the name of the people," nor has it spoken about "popular sovereignty" to designate self-authorship of judicial opinions in the name of a particular political community. Armin von Bogdandy noted that while "many domestic courts ... often decide in the name of the people' ... no supranational or international court states the basis of its authority in a similar fashion." ${ }^{279}$ Indeed, the ECtHR chose to use the phrase "public confidence" to designate support of the actual peoples of Europe. Only this reading of the ECtHR's use of the concept "public confidence" can be reconciled with the ECtHR's claim that "[ $t$ ] he persistence of conflicting court decisions, on the other hand, can create a state of legal uncertainty likely to reduce public confidence in the judicial system, whereas such confidence is clearly one of the essential components of a State based on the rule of law." 280 "Reduce" refers to reduction in a measurable metric. Had the ECtHR viewed "public confidence" as equivalent to "popular sovereignty," or as expressing a normative standard, it could not have used the verb "reduce."

Speaking of this measurable entity in place of the "popular sovereign" is an example of a general shift in current discourse. Measurable metrics replace, or at least embody, more abstract concepts. $^{281}$ This shift in understanding judicial legitimacy corresponds well with Schmitt's description of the shift in the understanding of the concept of sovereignty. According to Schmitt, during the nineteenth century, sovereignty was understood as residing immanently in "the people," an abstract being that is represented as having one united will. In the twentieth century, sovereignty is understood in terms of democratically aggregated will of actual individuals. ${ }^{282}$ Thus, Schmitt would not be surprised by the ECtHR's use of "public confidence" as referring to popular majorities. For him, the political conceptual-array necessarily corresponds to the metaphysics controlling the epoch. In line with this insight, both the shift in understanding sovereignty and the shift in understanding judicial legitimacy correspond to the era's great belief in democratic legitimacy and in assessment by measurement. ${ }^{283}$

But how can public confidence in the ECtHR be measured? There is no true one European public that supports or opposes the ECtHR. ${ }^{284}$ The peoples of the forty-seven member states do not create one public opinion. Moreover, there are not many opinion polls examining public support for the ECtHR. ${ }^{285}$ Yet by using the European Consensus (hereinafter: EuC) doctrine, the ECtHR has devised a complex mechanism to reflect the accumulation of public opinion stemming from the various national arenas.

The EuC doctrine is a tool of interpretation used in many cases by the ECtHR to decide whether a state's legal approach to a certain issue is acceptable. ${ }^{286}$ If there is an agreement between

\footnotetext{
${ }^{278}$ See VON BOGDANDY \& VENZKE, supra note 248, at 20.

${ }^{279}$ Armin von Bogdandy, The Democratic Legitimacy of International Courts: A Conceptual Framework, 14 THEO. INQ. L. 361, 364 (2013).

${ }^{280}$ Borg v. Malta, App. No. 37537/13, para. 107 (Jan. 12, 2016), http://hudoc.echr.coe.int/eng?i=001-159924 (emphasis added).

${ }^{281}$ See KAHN, supra note 35, at 12.

${ }^{282}$ See SchmitT, supra note 44, at 46-50. See also Benjamin A. Schupmann, LEVIATHAN Run Aground: CARL SCHMitT's State Theory and Militant Democracy 66-68 (PhD Thesis, Columbia University, 2015) [unpublished] (“Schmitt thus depicts political conceptions of legitimate sovereignty deriving from and running parallel to legitimate theological sovereignty.").

${ }^{283}$ See SCHMITT, supra note 44 , at $22,46-50$.

${ }^{284} \mathrm{Cf}$. vON BOGDANDY \& VENZKE, supra note 248, at 140 (noting in the context of the EU that "European democracy comes without positing a European people").

${ }^{285}$ See Erik Voeten, Public Opinion and the Legitimacy of International Courts, 14 THEO. INQ. L. 411, 423 (2013) ("I have been unable to trace comparative surveys about the ECtHR.").

${ }^{286}$ See Kanstantsin Dzehtsiarou, European Consensus and the Legitimacy of the European Court of Human RigHTS 17-21, 129 (2015) (surveying the variety of cases in which the European consensus doctrine has been used).
} 
a critical number of the forty-seven contracting states, or even an emerging trend on how to deal with a certain human rights issue, a state's ability to diverge from that emerging consensus is very limited. ${ }^{287}$ There is a rebuttable presumption that favors the majority of the contracting states' interpretation of the ECHR. ${ }^{288}$ A state can diverge from such a consensus only if it offers a compelling justification. ${ }^{289}$ The EuC is identified by a comparative analysis of the laws and practices of the contracting states. ${ }^{290}$

The logic of the EuC doctrine is majoritarian: Properly applying this doctrine in concrete cases is aimed at producing a result supported by most Europeans and most contracting states. One may contest the majoritarian assumption by arguing that a position that reflects the legislation or practice in the majority of contracting states does not necessarily reflect the opinion of the majority of Europeans. Yet, even while keeping in mind this and similar challenges to the EuC doctrine, it is hard to deny that the logic of polling the legal situation in the contracting states on a concrete issue is a deep majoritarian-democratic logic: In a democracy, we assume that the will of the people is reflected, by and large, in legislation. In this spirit, the US Supreme Court, which also relies in its decision-making on surveys of the legal situation in the various states of the US, stated several times that "the primary and most reliable indication of consensus is ... the pattern of enacted laws." 291

By using the EuC doctrine, the ECtHR aims to dissolve the counter-majoritarian character of its endeavor by following majority opinion, at least in some cases, and thus ensuring its public confidence. ${ }^{292}$ Even if there are cases in which ECtHR judges put aside European consensus because it hinders human rights, the general doctrinal guideline, as encapsulated in the EuC doctrine, is one partly premised on the logic of sociological legitimacy. By following the EuC doctrine, the ECtHR prefers securing public support, rather than following solely the logic of normative legitimacy and producing judgments that are justified in terms of human rights protection. As a result, there is an inbuilt contradiction or irony in the relationship between the majoritarian logic of the EuC doctrine and the mission of a human rights court to protect human rights even against popular will. ${ }^{293}$ After all, if human rights were always consensual, their protection would be achieved through the democratic process and no judicial intervention would be required to enforce them contrary to majority will. But because human rights often function as trump cards to defend minorities against the will of the majority, the creation of the EuC doctrine by a court whose name contains the phrase "human rights" seems to be a betrayal of its function, or at least puzzling. Keeping in mind that the ECtHR was envisioned, at least by some of the ECHR founders,

\footnotetext{
${ }^{287}$ See id. at 12-16; Eyal Benvenisti, Margin of Appreciation, Consensus, and Universal Standards, 31 NYU J. INT'L L. \& POL. 843, 851 (1999).

${ }^{288}$ See DzeHTSIAROU, supra note 286, at 208 ("European consensus can be conceptualized as a rebuttable presumption in favour of the rule or practice adopted by the majority of the Contracting Parties to the ECHR.").

${ }^{289}$ See Kanstantsin Dzehtsiarou, Does Consensus Matter? Legitimacy of European Consensus in the Case Law of the European Court of Human Rights, 2011 PUB. L. 534, 544 (2011); DzEHTSIAROU, supra note 286, at 27-29 (noting that a lack of consensus means a wide margin of appreciation); Shai Dothan, The Optimal Use of Comparative Law, 43 DENVER J. INT'L L. \& POL'Y 21, 26 (2015).

${ }^{290}$ See Dzehtsiarou supra note 286 , at 2, 24, 37-45.

${ }^{291}$ Stanford v. Kentucky, 492 U.S. 361, 373 (1989). See also Washington v. Glucksberg, 521 U.S. 702, 711 (1989); Corinna Barrett Lain, The Unexceptionalism of Evolving Standards, 57 UCLA L. REV. 365 (2009).

${ }^{292}$ See Jeffrey A. Brauch, The Dangerous Search For and Elusive Consensus: What the Supreme Court Should Learn from the European Court of Human Rights, 52 HowARD L.J. 277, 278 (2009) ("Both the ECHR (to a great extent) and [the American] Supreme Court (to a lesser, yet important extent) are resolving important rights claims by looking to a factor that ought to have no role in determining the scope or content of either human or constitutional rights: societal consensus.").

${ }^{293}$ See Jeffrey A. Brauch, The Margin of Appreciation and the Jurisprudence of the European Court of Human Rights: Threat to the Rule of Law, 11 Colum. J. Eur. L. 113, 146 (2004); Kanstantsin Dzehtsiarou, Interaction Between the European Court of Human Rights and Member States: European Consensus, Advisory Opinions and the Question of Legitimacy, in THE EUROPEAN Court of Human Rights and its Discontents: Turning Criticism into Strength 116, 119-20 (Spyridon Flogaitis, Tom Zwart \& Julie Fraser eds., 2013) (quoting Letsas).
} 
as a response to the Weimar lessons helps to better understand the logic that led the ECtHR along this seemingly contradictory path. The ECtHR's mission was envisioned at the outset as one of guarding democracy as a regime that positions human rights at its core, rather than as a court that decides on thousands of human rights violations. ${ }^{294}$ Yet, the lesson at the core of the Schmitelsen court is that, in order to protect the regime's political decision, a court must acquire the support of the public.

\section{F. Conclusion}

The Weimar experience continues to haunt us. ${ }^{295} \mathrm{With}$ the rise of populist movements worldwide, the lessons learned from the collapse of the Weimar Republic seem more relevant than ever. The need for a strong judicial body to protect the fundamental structures of democracy against threats from populist movements is frequently presented as a lesson learned from the Weimar experience. Yet, a current analysis of the debate between Kelsen and Schmitt on the identity of the guardian of the constitution shows that the picture is more complicated.

First and foremost, in many systems, the terms according to which judicial legitimacy is understood have profoundly changed since the Kelsen-Schmitt debate. We are in the midst of a paradigm shift. In recent decades, several courts worldwide have begun to understand their legitimacy in terms of public support. This important development in world constitutionalism has been hidden in plain sight from both the public and scholarly eye. It has been hidden because the terms used for discussing judicial legitimacy remained the same while their content changed. It is important to stress that the idea that judicial legitimacy is based on public support was not concealed. Indeed, my entire point is that in several legal systems, the prevalent understanding of judicial legitimacy is now in terms of public support. This understanding has become a myth in the Barthesian sense. It has become natural or commonsensical and hence hidden in plain sight. ${ }^{296}$ What has been concealed is that a shift had occurred in understanding judicial legitimacy. The Kelsen-Schmitt debate allows us to see this shift vividly. Both theorists viewed the judiciary as unable to rely on public support as its source of legitimacy. Each of them deduced different conclusions from this shared understanding of judicial legitimacy for the debate over who is the guardian of the constitution. Now, compare their understanding to Barry Friedman's excellent 2009 book The Will of the People: How Public Opinion has Influenced the Supreme Court and Shaped the Meaning of the Constitution. ${ }^{297}$ Friedman's account of the relationship between public opinion and the US Supreme Court throughout its history fails to distinguish between the period before the invention of public opinion polls and the period afterwards. ${ }^{298}$ The story, according to Friedman, is one of a structurally unchanged relationship between public opinion and the Court. In essence, according to his account, judicial legitimacy was always understood in terms of public opinion; the only change is that with time, the justices have become better in assessing public opinion. ${ }^{299}$ Friedman's book is but one example out of many accounts on the relationships between courts and public opinion that are written in the US according to the new controlling paradigm. These accounts "read" the past according to this paradigm. They miss the profound

\footnotetext{
${ }^{294}$ Marco Duranti, The Conservative Human Rights Revolution 3 (2017) (explaining the "conventional understanding of the genesis of the ECHR, which posit that its progenitors only had their minds the defense of democracies in the continent").

${ }^{295}$ See, e.g., Daniel Bessner \& Udi Greenberg, The Weimar Analogy, JACOBIN (Dec. 7, 2016) ("In newspapers and on talk shows, commentators are quick to warn that the United States is going the way of 1930s German democracy.").

${ }^{296}$ See Roland Barthes, MYthologies 129 (Annette Lavers trans., 1972) (1957) ("We reach here the very principle of myth: it transforms history into nature.").

${ }^{297}$ Barry Friedman, The Will of the People: How Public Opinion Has Influenced the Supreme Court and Shaped the Meaning of the Constitution (2009).

${ }^{298}$ For my critique of Friedman's account, see Bassok, supra note 131, at 192-93.

${ }^{299}$ FrIEDMAN, supra note 297 , at 376.
} 
shift that has occurred, a shift that is made evident once the Kelsen-Schmitt debate looms in the background.

Second, by incorporating into its institutional design the recent shift in understanding judicial legitimacy, the Schmitelsen guardian seems to encapsulate lessons learned from the KelsenSchmitt debate. On the one hand, the Schmitelsen guardian is in line with Kelsen's guardian: The role of the guardian is entrusted to a court that is designed to adhere to legal reason rather than to populist pressures that may tempt elected representatives. On the other hand, the Schmitelsen guardian embraces Schmitt's insight that in order to protect the constitution's political decision, the guardian must enjoy the support of the people. A guardian with the Kelsenian guardian's constraints and the Schmittian guardian's power seems to be the prefect recipe to confront the serious threats democracies have been facing in recent times.

Yet, the Schmitelsen model presents two major difficulties stemming from the question of legitimacy. First, courts that understand judicial legitimacy in terms of public support find it very difficult to separate the need to maintain their Schmittian source of legitimacy from their duty to decide according to the Kelsenian criterion of professional legal expertise. Decisions in any language of expertise are supposed to be made according to professional criteria, and not according to a head count. ${ }^{300} \mathrm{~A}$ court that views its legitimacy in terms of public support may digress to adjudicating according to public opinion. It may become a populist guardian. While viewing judicial legitimacy in terms of public support does not necessitate deciding according to public opinion, it has great potential to corrupt the language of legal expertise in order to accommodate public opinion. ${ }^{301}$

The second difficulty emanates from the possibility of the guardian losing public support. While in many countries, the rise of judicial power has been supported by the public, ${ }^{302}$ there is always the danger that support for the guardian of the constitution would dwindle. Exhibit A for the rise of judicial power worldwide-the ISC - serves as an alarming example. During the first decade of the twenty-first century, the ISC experienced a sharp decline in its public support according to opinion polls. ${ }^{303}$ The ISC suddenly found it extremely difficult to continue to refer to "public confidence" in the judiciary as its source of legitimacy, when opinion polls showed that the majority of the public lacked confidence in the ISC. ${ }^{304}$ A Schmiteslen Court that views its legitimacy in terms of public support is always exposed to the danger that support for the guardian of the constitution could dwindle.

\footnotetext{
${ }^{300}$ See Robert C. Post, Democracy, Expertise, and Academic Freedom xii-xiv, 8, 29-32, 54 (2012).

${ }^{301}$ See Or Bassok, The Arendtian Dread: Courts with Power, 30 RATIO JuRIs 417, 424-27 (2017).

${ }^{302}$ See James L. Gibson, Gregory A. Caldeira \& Vanessa A. Baird, On the Legitimacy of National High Courts, 92 AM. POL. SCI. REv. 343 (1998) (surveying data on public support of national high courts from twenty countries); ALEC STONE SwEET, GOVERNING WITH JUdGes 139 (2000) (noting that in Europe constitutional courts have high "institutional legitimacy"); Wojciech SAdurski, Rights Before Courts 33 (2005) ("[I]t is indisputable that the constitutional courts in the region discussed here [Central and Eastern Europe] enjoy a high level of social acceptance, despite occasional disagreements with and criticisms of particular decisions. They do not, therefore, have a problem with 'legitimacy' in the sense of a general public acceptance of their authority to do what they are doing - including the invalidation of statues.").

${ }^{303}$ See Asher Arian, et Al., Auditing Israeli Democracy 2008: Between the State and Civil Society 54 (2008); Bassok, supra note 210, at 307-08.

${ }^{304}$ See Bassok, supra note 244, at 67-69 (describing how Dorit Beinisch, the President of the ISC after Barak's retirement, struggled with the idea that the Court's legitimacy stems from "public confidence" in a period in which public opinion polls showed a steep decline in public support for the ISC).
}

Cite this article: Bassok O (2020). The Schmitelsen Court: The Question of Legitimacy. German Law Journal 21, $131-162$. https://doi.org/10.1017/glj.2020.2 